\title{
Synthesis of poly(aryl ether)s bearing phosphonated side-chains from phosphonate ester-containing bisphenols
}

\author{
Catherine Marestin ${ }^{(1)}$, Saber Chatti ${ }^{(2)}$, Regis Mercier ${ }^{(1)}$ \\ ${ }^{(1)}$ Université de Lyon, INSA-Lyon, CNRS, IMP UMR 5223, \\ F-69 621 Villeurbanne Cedex, France \\ ${ }^{(2)}$ National Institute of Research and Physico-chemical Analysis (INRAP), Biotechnopole of \\ Sidi Thabet, 2020 Ariana, Tunisia
}

Corresponding author : catherine.marestin@insa-lyon.fr

\begin{abstract}
As part of our project research to design aromatic polymers with pendant acid groups, we have paid efforts to synthesize phosphonic acid-containing poly(aryl ether)s (PAEs) from functionalized monomers. To this end, two bisphenol monomers bearing phosphonic ester groups were synthesized. A study of the polymerization reaction via model compound preparation point out specific experimental conditions to prevent side reactions between phosphonic ester functions and phenolate monomers. Based on these experimental optimised conditions, different PAEs with high molecular weights were prepared. Free acid phosphonic groups-containing PAE were obtained by subsequent controlled hydrolysis of phosphonate ester groups.
\end{abstract}

\section{Keywords}

Phosphonate ester-containing bisphenol, Phosphonated poly(aryl ether)s, Aromatic nucleophilic substitution. 


\section{Introduction}

Because of their specific chemical structure, phosphonic acid groups provide interesting properties $^{[1]}$. Therefore, phosphonic acid-containing polymers have aroused interest in many different domains, such as materials for dental cements ${ }^{[2,3]}$, adhesion promoters ${ }^{[4]}$, anticorrosive coatings ${ }^{[5]}$, chemical sensors ${ }^{[6]}$, scale inhibitor in water treatment ${ }^{[7]}$ or even for fuel cells membranes ${ }^{[8-10]}$. In the frame of the development of new high performance thermostable materials, the synthesis of innovative macromolecular structures is of outmost importance. In this context, the design of phosphonic acid-containing aromatic and heterocyclic polymers could provide interesting properties and open new perspectives for the development of high performance materials.

A convenient approach used to introduce phosphonic acid groups along a polymer chain consists in the chemical-modification of high molecular weight pre-existing polymers. In this respect, different aromatic and heterocyclic polymer structures have been investigated, such as $\quad\left(\right.$ poly(phosphazene)s ${ }^{[11-14]}$, poly(oxadiazoles)s ${ }^{[15]}$, poly(paraphenylene)s ${ }^{[16]}$, poly(benzimidazole $)^{[17]}$, poly(diimidazopyridine) $\mathrm{s}^{[18]}$ and the most extensively studied poly(aryl ether)s. Phosphonic acid groups can be incorporated by different chemical reactions (Arbusov or Michaelis-Arbusov reaction ${ }^{[19]}$, lithiation and direct phosphonation ${ }^{[20]}$, reaction with a phosphonate containing reactant ${ }^{[21]}$ or a iodobenzoyl reactant ${ }^{[22]}$, by nickel-catalyzed ${ }^{[23,}$ ${ }^{24]}$ or palladium catalysed phosphonation ${ }^{[25-27]}$, N-alkylation ${ }^{[28]}$ or even by polymerization of vinylphosphonic side-chains ${ }^{[29]}$....). However, due to harsh reaction conditions (long reaction times, high temperature and low yields), such post-modifications usually induce some undesirable chain breaking or cross-linking. As a consequence, this strategy leads to a limited control of the degree of modification and also of the structural integrity of polymers. On the other hand, the polymerization of a functionnalized precursor is considered as a much more promising approach. In this connection, some phosphonated aromatic monomers have been described so far (Figure 1). They either present phosphonate ester or phosphonic acid groups which are directly grafted on the aromatic structure $(4,7,10,11,12)$ or bounded on a sidechain $(1,9,2,3,5,6,8)$. In all cases, multi-step syntheses are required to design such specific monomers.

Differents types of polymers were prepared from these monomers. Alvares et al ${ }^{[30]}$ report the synthesis of phosphonic acid containing polyimides based on diamine (1). Yasuda and co- 
workers $^{[31]}$, describe the synthesis of diamine (2) and studied its polymerization with a non functionalized diamine (CARDO) and NTDA.

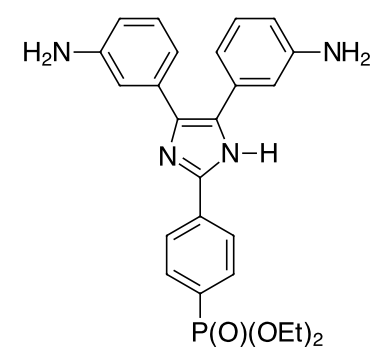

(1)<smiles></smiles>

(4)

$(\mathrm{BuO})_{2}(\mathrm{O}) \mathrm{P}$<smiles>O=C(O)c1ccc2c(c1)P(=O)(O)c1cc(C(=O)O)ccc1O2</smiles>

(5)

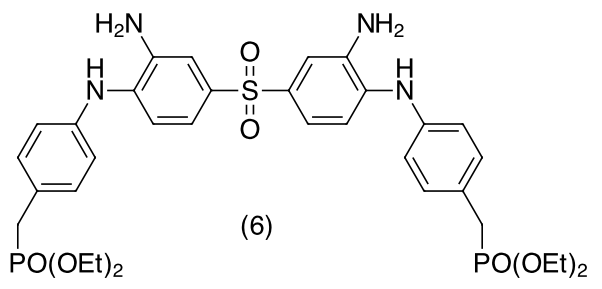

(2)

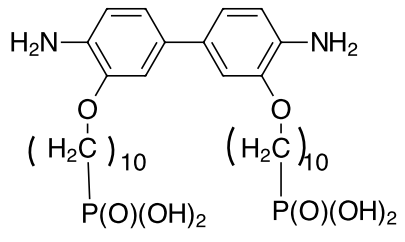

(9)
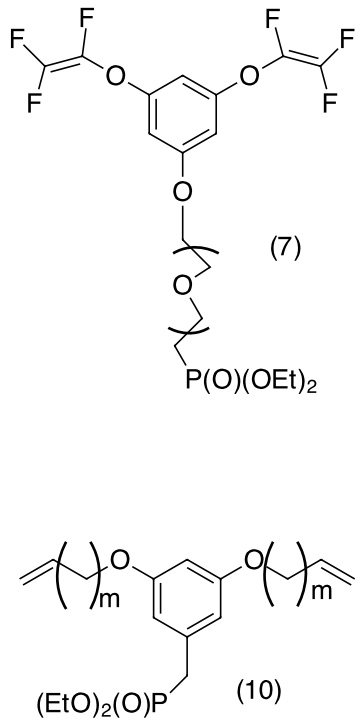

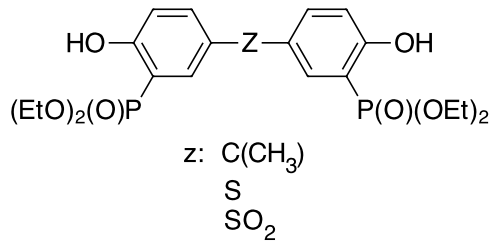

(12)

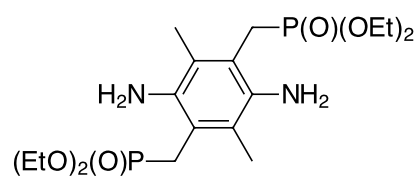

(3)
(8)

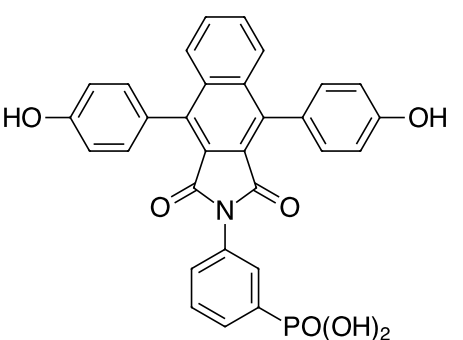

(11)

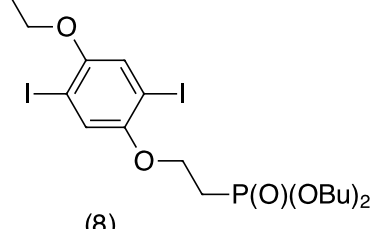


oxadiazole)s ${ }^{[15]} \cdot 10$-hydroxy-10-oxo-10H-10 $\lambda^{5}$ phenoxaphosphine-2,8 dicarboxylic acid (5) and diamine (6) were used by Ponomarev et al. to synthesize remarquable thermooxidative resistant polybenzoimidazoles ${ }^{[35,36]}$. Monomer (5) was used as well to synthesize 2,3,5,6tetraaminopyridine-based poly(heteroarylene) $\mathrm{s}^{[37]}$. Other polycondensation reactions were investigated, such as the cyclodimerization of phosphonate bistrifluorovinylether monomer $(7)^{[38]}$, the Sonogashira polymerization of (8) with 1,4 diethynylbenzene ${ }^{[39]}$, or the Colon coupling reaction with $(9)^{[16]}$. Very recently, phosphonic acid containing polyethylene structures were synthesized by step-growth metathesis of functionalized monomer $(10)^{[40]}$. However, materials with rather low molecular weight were usually reported. The synthesis of phosphonic acid-containing Poly(aryl ether)s was also considered from different functionalized bisphenol monomers $\left((11)^{[41,42]},(12)^{[43-45]},(13)^{[45-48]}\right.$ and $\left.(14)^{[49]}\right)$. Rather few examples of the incorporation of these phosphonated precursors in the synthesis of poly(aryl ether)s by aromatic nucleophilic substitution are reported. When copolymerized with 4,4' difluorodiphenylsulfone or 4,4'-difluorotriphenylphosphine oxide, only low molecular weight polymers are described from the diphosphonated bisphenols. The authors ascribe this result to the sterical hindrance of the bulky phosphonate groups present on the functionalized biphenol $^{[48]}$. High molecular weight polymers were however synthesized by 4,4', difluorodiphenylsulfone and the monophosphonated bisphenol (14) or using a more reactive comonomer such as decafluorobiphenyl ${ }^{[47]}$. High molecular weight poly(aryl ether)s containing from $25 \%$ to $100 \%$ of a phosphonic acid containing bisphenol-imide (11) are also reported by Meng et al. ${ }^{[50]}$

Besides the difficulties encountered for the synthesis of the phosphonated precursors, the direct polycondensation of these functionnalized monomers (whatever the nature of the polymerization reaction) often results in the formation of low molecular weight oligomers. This is generally ascribed to possible strong aggregations phenomena, phosphonic acid condensation reactions or low reactivity of the functionnalized monomer. As a result, the synthesis of high molecular weight polymers with a high extend of phosphonic acid groups is rather challenging. In this article, we describe the straightforward synthesis of two side-chain phosphonate ester-containing bisphenols. A thorough study of an aromatic nucleophilic substitution involving this precursor was then performed on a model molecule in order to identify possible undesirable side-reactions that could be detrimental during a polycondensation reaction. In the light of the obtained results, new insights are given for the synthesis of high molecular weight phosphonate esters and phosphonic acid-containing poly(aryl ether)s. 


\section{Experimental Section}

\subsection{Materials}

2,2-Bis(4-hydroxyphenyl)propane (Bisphenol A) (Sigma-Aldrich) was recrystallized from toluene, 4,4'-difluorobenzophenone (ACROS) was purified by crystallization from a petroleum ether / ethyl acetate mixture, 4,4'-difluorodiphenyl sufone (Aldrich) was purified by sublimation and 5-chloropentanone (Alfa Aesar) was distilled prior to use. Dimethyl sulfoxide (DMSO) (VWR Chemical Co.), toluene (SDS Chemical Co.), potassium carbonate and other chemicals (phenol, triethyl phosphite, 4-fluorobenzophenone, etc.) were commercially available and used as received.

\subsection{Characterization Methods}

Nuclear magnetic resonance $\left({ }^{1} \mathrm{H},{ }^{13} \mathrm{C}{ }^{19} \mathrm{~F}\right.$ and ${ }^{31} \mathrm{P}$ NMR) spectra were recorded on a Bruker Avance 400 spectrometer operating at the following frequencies of $400.16 \mathrm{MHz}$ for ${ }^{1} \mathrm{H}$, 100.63 MHz for ${ }^{13} \mathrm{C}, 376.48 \mathrm{MHz}$ for ${ }^{19} \mathrm{~F}$ and $161.99 \mathrm{MHz}$ for ${ }^{31} \mathrm{P}$. Tetramethylsilane was used as the internal standard for ${ }^{1} \mathrm{H}$ and ${ }^{13} \mathrm{C}$ spectra whereas $85 \% \mathrm{H}_{3} \mathrm{PO}_{4}$ was used as the reference for ${ }^{31} \mathrm{P}$ analyses.

Thermogravimetric analyses (TGA) were performed on a TA Instruments Q50. Samples were heated under air at $10^{\circ} \mathrm{C} / \mathrm{min}$. The polymer glass transition temperatures $\left(\mathrm{T}_{g}\right)$ were determined by Differential Scanning Calorimetry (DSC) with a Mettler-Toledo DSC822e equipment (measurements were performed at a heating rate of $10{ }^{\circ} \mathrm{C} / \mathrm{min}$, under nitrogen) and by Thermo mechanical analyses (TMA) on a TA Instruments model Q400 (measurements were performed under nitrogen, at a heating rate of $10{ }^{\circ} \mathrm{C} / \mathrm{min}$, in the penetration mode, on thin polymer films).

The polymer molecular weights were evaluated by Size Exclusion Chromatography (SEC) in DMF containing 0.05M LiBr. The system used was equipped with an AGILENT G1310A pump, two PLgel Mixed D columns thermostated at $70^{\circ} \mathrm{C}$ and a Wyatt optilab differential refractive index detector. Molecular weights (denoted $\mathrm{M}_{n(P S)}$ and $\mathrm{M}_{w(P S)}$ ) were determined from a polystyrene calibration curve.

\subsection{Synthesis of Reagents and Monomers}

Synthesis of 1-Chloro-4,4-di(p-hydroxyphenyl)-pentane (I). $41.68 \mathrm{~g}(0.3456 \mathrm{~mol})$ of freshly distilled 5-chloropentanone, $130.126 \mathrm{~g}$ (1.3826 mol) of phenol, few drops of mercaptoacetic acid and few drops of sulfuric acid were introduced in a $250 \mathrm{~mL}$ three-necked round bottom flask. $\mathrm{HCl}$ was then bubbled through the reaction medium, at room temperature. The reaction 
proceeded overnight. The solid obtained was dispersed into water. The product was isolated by filtration and purified by column chromatography (successively with $\mathrm{CH}_{2} \mathrm{Cl}_{2}$ and acetone), leading to 1-chloro-4,4-di(p-hydroxyphenyl)-pentane as a pure white powder (83.4\% yield). ${ }^{1} \mathrm{H}$ NMR (d 6 -DMSO): $\delta(\mathrm{ppm}) 1.49(\mathrm{~m}, 5 \mathrm{H}), 2.07(\mathrm{~m}, 2 \mathrm{H}), 3.54(\mathrm{t}, 8 \mathrm{~Hz}, 2 \mathrm{H}), 6.65(\mathrm{~d}, 8 \mathrm{~Hz}$, $4 \mathrm{H}), 6.95(\mathrm{~d}, 8 \mathrm{~Hz}, 4 \mathrm{H}) .{ }^{13} \mathrm{C} \mathrm{NMR}\left(\mathrm{d}_{6}\right.$-DMSO): $\delta$ (ppm) 27.5, 28.1, 38.7, 43.8, 45.9, 114.6, 127.7, 139.6, 154.9.

Synthesis of 1-Iodo-4,4-di(p-hydroxyphenyl)-pentane (II). $23.3 \mathrm{~g}\left(8.0110^{-2} \mathrm{~mol}\right)$ of 1-chloro4,4-di(p-hydroxyphenyl)-pentane were dissolved in $122 \mathrm{~mL}$ of reagent grade acetone. $48.04 \mathrm{~g}$ $(0.32 \mathrm{~mol})$ of $\mathrm{NaI}$ were added to the solution and the reaction mixture was heated at reflux. The evolution of the reaction was monitored by ${ }^{1} \mathrm{H}$ NMR. After the reaction was completed, the solvent was evaporated and the target product was isolated from the remaining $\mathrm{NaI}$ salts by extraction with dichloromethane. The organic layer was then concentrated and dried under vacuum. $22.6 \mathrm{~g}$ (74\% yield) of 1-iodo-4,4-di(p-hydroxyphenyl)-pentane were obtained. ${ }^{1} \mathrm{H}$ NMR (d $\left.\mathrm{d}_{6}-\mathrm{DMSO}\right): \delta(\mathrm{ppm})$ 1.47-1.56 (m, 5H), 2.02-2.07 (m, 2H), $3.2(\mathrm{t}, 4 \mathrm{~Hz}, 2 \mathrm{H}), 6.65(\mathrm{~d}$, $8 \mathrm{~Hz}, 4 \mathrm{H}), 6.94$ (d, 8Hz, 4H), $9.17(\mathrm{OH}) .{ }^{13} \mathrm{C}$ NMR (d 6 -DMSO): $\delta$ (ppm) 9.90, 28.2, 29.53, $42.9,44.3,115.1,128.2,140.1,155.4$.

Synthesis of Ethyl 4,4-di(p-hydroxyphenyl)pentanephosphonate (A). $1 \mathrm{~g}$ (2.6 mmol) of 1-iodo4,4-di(p-hydroxyphenyl)-pentane were introduced in a $25 \mathrm{~mL}$ round botton flask equipped with a nitrogen inlet and a condenser. $0.869 \mathrm{~g}(5.2 \mathrm{mmol})$ of triethylphosphite were added dropwise. The reaction mixture was then heated at $110^{\circ} \mathrm{C}$ and the evolution of the reaction was monitored both by ${ }^{1} \mathrm{H}$ and ${ }^{31} \mathrm{P}$ NMR. After the reaction was completed, the excess of triethylphosphite was distilled at $160{ }^{\circ} \mathrm{C}$ under vacuum. Ethyl 4,4-di(phydroxyphenyl)pentanephosphonate was obtained as a vitrous product with $95 \%$ yield . The polymer-grade phosphonated monomer was obtained as a white powder by flash chromatography. ${ }^{31} \mathrm{P}$ NMR (d ${ }_{6}$-DMSO): $\delta$ (ppm) 31.78. ${ }^{1} \mathrm{H}$ NMR (d 6 -DMSO): d (ppm) 1.17 (t, $1.8 \mathrm{~Hz}, 3 \mathrm{H}), 1.28-1.30(\mathrm{~m}, 2 \mathrm{H}), 1.48(\mathrm{~s}, 3 \mathrm{H}), 1.60-1.68(\mathrm{~m}, 2 \mathrm{H}), 3.86-3.96(\mathrm{~m}, 4 \mathrm{H}), 6.63(\mathrm{~d}$, $8 \mathrm{~Hz}, 4 \mathrm{H}), 6.93(\mathrm{~d}, 8 \mathrm{~Hz}, 4 \mathrm{H}), 9.2(\mathrm{OH}) .{ }^{13} \mathrm{C}$ NMR $\left(\mathrm{d}_{6}-\mathrm{DMSO}\right): \delta(\mathrm{ppm}) 16.1,17.6,24.7(\mathrm{~d}$ 27.4, 42.3, 44.1, $60.6114 .5,127.6,139.6,154.8$.

Synthesis of 1-Bromo-3-(trifluoroacetylphenyl)-propane (III). In a three-necked round bottom flask equipped with a condenser, a magnetic stirrer and a nitrogen inlet, $23.47 \mathrm{~g}(0.176 \mathrm{~mol})$ of $\mathrm{AlCl}_{3}$, were suspended in $240 \mathrm{~mL}$ of $\mathrm{CH}_{2} \mathrm{Cl}_{2}$. The reaction mixture was cooled in an ice bath. $21.94 \mathrm{~g}(0.104 \mathrm{~mol})$ of trifluoroacetic anhydride were added and temperature was kept below $5^{\circ} \mathrm{C}$. A solution made out of $16 \mathrm{~g}(0.08 \mathrm{~mol})$ of 1-Bromo-3-phenylpropane in $80 \mathrm{~mL}$ 
$\mathrm{CH}_{2} \mathrm{Cl}_{2}$ was added dropwise. After the end of the addition, the reaction mixture was stirred 30 minutes at room temperature. The evolution of the reaction was monitored by thin layer chromatography. After completion of the reaction, the mixture was poured into water. The product was isolated by extraction (EtOAc). The organic phase was dried other $\mathrm{Na}_{2} \mathrm{SO}_{4}$ and the solvent was evaporated. The yellowish liquid was distilled $\left(85^{\circ} \mathrm{C}-510^{-2}\right.$ mbar $)$ giving $20.38 \mathrm{~g}(86 \%$ yield $)$ of a colorless liquid. ${ }^{19} \mathrm{~F}$ NMR $\left(\mathrm{d}_{6}\right.$-DMSO): $\delta(\mathrm{ppm})-70.75 .{ }^{1} \mathrm{H}$ NMR $\left(\mathrm{d}_{6^{-}}\right.$ DMSO): d (ppm) 2.17 (m, 2H), 2.88 (t, 2H, J = $8 \mathrm{~Hz}), 3.55$ (t, 2H, J = 6.5 Hz), 7.55 (d, 2H, J $=8 \mathrm{~Hz}), 8.0(\mathrm{~d}, 2 \mathrm{H}, \mathrm{J}=8 \mathrm{~Hz}),{ }^{13} \mathrm{C} \mathrm{NMR}\left(\mathrm{d}_{6}-\mathrm{DMSO}\right): \delta(\mathrm{ppm}) 33.3,33.8,34,118.89\left(\mathrm{CF}_{3}\right)$, $127.7,129.5,130.1,150.2,179.69$ (q).

Synthesis of 1,1-Bis-(3,5-dimethyl-4-hydroxyphenyl)-1-(4-(3-bromopropyl)-phenyl)-2,2,2trifluoroethane $(I V)$. In a three-necked round bottom flask were introduced $15 \mathrm{~g}(0.0508 \mathrm{~mol})$ of freshly distilled 1-bromo-3-(trifluoroacetylphenyl)-propane (III), $20 \mathrm{~g}$ (0.163 mol) of 2,6dimethylphenol and $0.346 \mathrm{~g}(0.002 \mathrm{~mol})$ of zinc chloride. $\mathrm{HCl}$ was bubbled through the reaction mixture and temperature was raised up to $100{ }^{\circ} \mathrm{C}$ and maintained overnight. The reaction mixture was poured into water, washed with deionized water and dried under vacuum. $22.84 \mathrm{~g}\left(86.2 \%\right.$ yield) of crude product were obtained. ${ }^{19} \mathrm{~F}$ NMR ( $\mathrm{d}_{6}$-DMSO): $\delta$ (ppm) -57.68. ${ }^{1} \mathrm{H}$ NMR (d $\left.\mathrm{d}_{6}-\mathrm{DMSO}\right): \delta(\mathrm{ppm}) 2.07$-2.14 (m, 5H), $2.72(\mathrm{t}, 2 \mathrm{H}), 3.51(\mathrm{t}, 2 \mathrm{H})$, $6.57(\mathrm{~s}, 4 \mathrm{H}), 6.96\left(\mathrm{~d}, 2 \mathrm{H}, 7.19(\mathrm{~d}, 2 \mathrm{H}), 8.38(\mathrm{OH}) .{ }^{13} \mathrm{C} \mathrm{NMR}\left(\mathrm{d}_{6}\right.\right.$-DMSO): $\delta(\mathrm{ppm}) 16.9,32.8$, $33.5,34.3,62.8$ (q), 123.5, 127.9, 129.3, 129.4, 130.3, 138.1, 139.8, 152.5.

Synthesis of 1,1-Bis-(3,5-dimethyl-4-hydroxyphenyl)-1-(4-(3-iodopropyl)-phenyl)-2,2,2trifluoroethane $(V) .22 \mathrm{~g}(0.0422 \mathrm{~mol})$ of $(5)$ and $25.29 \mathrm{~g}(0.168 \mathrm{~mol})$ of NaI were suspended in $115 \mathrm{~mL}$ of reagent grade acetone, in a $250 \mathrm{~mL}$ single-neck round bottom flask equipped with a magnetic stirrer and a condenser. The reaction mixture was heated at reflux. The evolution of the reaction was monitored by ${ }^{1} \mathrm{H}$ NMR. After completion of the reaction, the sodium bromide formed during the reaction was filtered and the filtrate was evaporated, giving an orange solid. Remaining traces of $\mathrm{NaI}$ were removed by extraction $\left(\mathrm{CH}_{2} \mathrm{Cl}_{2} / \mathrm{H}_{2} \mathrm{O}\right)$. The organic phase was evaporated and dried in vacuo, giving $(\mathrm{V})$ with $87.5 \%$ yield. ${ }^{19} \mathrm{~F}$ NMR (d $\mathrm{d}_{6}$-DMSO): $\delta(\mathrm{ppm})-57.67{ }^{1} \mathrm{H}$ NMR (d $\mathrm{d}_{6}$-DMSO): $\delta(\mathrm{ppm}) 2.05-2.08(\mathrm{~m}, 5 \mathrm{H}), 2.66(\mathrm{t}, 2 \mathrm{H})$, $3.23(\mathrm{t}, 2 \mathrm{H}), 6.55(\mathrm{~s}, 4 \mathrm{H}), 6.94(\mathrm{~d}, 2 \mathrm{H}), 7.17(\mathrm{~d}, 2 \mathrm{H}), 9.6(\mathrm{OH}) .{ }^{13} \mathrm{C}$ NMR (d $\mathrm{d}_{6}$-DMSO): $\delta(\mathrm{ppm})$ 8.12, 17.4, 34.7, 35.6, 63.3 (q), 123.9, 128.4, 129.8, 129.9, 130.8, 138.7, 140.1, 152.9.

Synthesis of 1,1-Bis-(3,5-dimethyl-4-hydroxyphenyl)-1-(4-(3-diethylphosphonatopropyl)phenyl)-2,2,2-trifluoroethane (B). In a three-necked round bottom flask equipped with a magnetic stirrer, a nitrogen inlet and a condenser were introduced $10 \mathrm{~g}(0.0191 \mathrm{~mol})$ of 1,1- 
Bis-(3,5-dimethyl-4-hydroxyphenyl)-1-(4-(3-bromopropyl)-phenyl)-2,2,2-trifluoroethane (respectively $21 \mathrm{~g}(0.036 \mathrm{~mol})$ of $(\mathrm{V}))$ and $6.58 \mathrm{ml}$ of triethylphosphite (resp $12.7 \mathrm{ml})$. The reaction mixture was heated at $110{ }^{\circ} \mathrm{C}$ for 12 hours. The temperature was raised to $160{ }^{\circ} \mathrm{C}$ in order to distill off all remaining volatile compounds. The vitrous resulting product was dissolved in dichloromethane and purified by column chromatography $\left(\mathrm{CH}_{2} \mathrm{Cl}_{2}, \mathrm{EtOH}\right)$, giving $8.5 \mathrm{~g}$ (76.6\% yield) resp $17.2 \mathrm{~g}$ (80.4\% yield) of polymer grade (B). ${ }^{19} \mathrm{~F}$ NMR (d6DMSO): $\delta$ (ppm) -57.52. ${ }^{31} \mathrm{P}$ NMR: (d $\mathrm{d}_{6}$-DMSO): $\delta$ (ppm) 31.49. ${ }^{1} \mathrm{H}$ NMR $\left(\mathrm{d}_{6}\right.$-DMSO): $\delta(\mathrm{ppm}) 1.18(\mathrm{t}, 6 \mathrm{H}), 1.6-1.8(\mathrm{~m}, 4 \mathrm{H}), 2.06(\mathrm{~s}, 12 \mathrm{H}), 2.63(\mathrm{t}, 2 \mathrm{H}), 3.94(\mathrm{~m}, 4 \mathrm{H}), 6.54(\mathrm{~s}, 4 \mathrm{H})$, $6.93(\mathrm{~d}, 2 \mathrm{H}), 7.15$ (d, 2H), $8.4(\mathrm{OH}) .{ }^{13} \mathrm{C}$ NMR (d 6 -DMSO): d (ppm) 16.1, 16.19, 22.9, 23.7, $25.1,34.8(\mathrm{~d}), 60.78,63.2$ (q), 123.5, 127.9, 129.3, 130.4, 138.1, 140.3, 152.5.

Study of the reaction of potassium carbonate on hemi-phosphonate ester groups $2 \mathrm{~g}(0.0082 \mathrm{~mol})$ of diethyl[(4-methylphenyl)methyl]phosphonate, $3.48 \mathrm{~g}(0.033 \mathrm{~mol})$ of potassium carbonate, $25 \mathrm{ml}$ of toluene (cyclohexane) and $11.5 \mathrm{ml}$ of DMSO were introduced in a three-necked round bottom flask equipped with a nitrogen inlet, a mechanical stirrer and a dean stark trap. The reaction medium was heated at $140{ }^{\circ} \mathrm{C}\left(110^{\circ} \mathrm{C}\right)$ for 4 hours. After azeotropic distillation of the water formed, the reaction medium was heated at $160{ }^{\circ} \mathrm{C}(110$ ${ }^{\circ} \mathrm{C}$ ) for 20 hours. Samples were directly withdrawn from the reaction medium and few drops of deuterated DMSO were added. Quantitative ${ }^{31} \mathrm{P}$ NMR spectra were recorded at $30{ }^{\circ} \mathrm{C}$.

\section{Model molecule synthesis}

$1 \mathrm{~g}(0.0025 \mathrm{~mol})$ of $(\mathrm{A}), 1.021 \mathrm{~g}(0.005 \mathrm{~mol})$ of 4-fluorobenzophenone, $0.718 \mathrm{~g}(0.0052 \mathrm{~mol})$ of potassium carbonate were suspended in $10 \mathrm{ml}$ of DMSO. The reaction mixture was heated at $160{ }^{\circ} \mathrm{C}$ for 9 hours. The evolution of the reaction was monitored both by ${ }^{19} \mathrm{~F}$ and ${ }^{31} \mathrm{P}$ NMR. After the reaction was completed (as evidenced by ${ }^{19} \mathrm{~F}$ NMR), the reaction medium was poured into acidic water. The resulting beige compound was filtrated, washed with petroleum ether and dried under vacuum (yield 89.5\%).

\subsection{General procedures for the synthesis of phosphonate ester-containing poly(aryl ether)s} Synthesis of phosphonate ester-containing poly(aryl ether ketone)s (PAEK).

$2 \mathrm{~g}$ (5 mmol) of Ethyl 4,4-di(p-hydroxyphenyl)pentanephosphonate (A), $2.19 \mathrm{~g}$ (10 mmol) of 4,4'-difluorobenzophenone, $1.13 \mathrm{~g}(5 \mathrm{mmol})$ of Bisphenol A and $4.2 \mathrm{~g}$ (30 mmol) of potassium carbonate, $20 \mathrm{~mL}$ of DMSO (or NMP, or DMAC) and $15 \mathrm{~mL}$ of toluene were introduced in a two-necked reactor equipped with a nitrogen inlet and a mechanical stirrer. The reaction mixture was heated at $140{ }^{\circ} \mathrm{C}$ for 4 hours. After azeotropic distillation of the 
water formed, the temperature was raised to $160{ }^{\circ} \mathrm{C}-180{ }^{\circ} \mathrm{C}$ and heated for 24 to 39 hours. After cooling, the mixture was poured into water. The resulting polymer was collected by filtration, washed with water and dried under vacuum at $80^{\circ} \mathrm{C}$, for 4 hours.

Typical procedure for the synthesis of phosphonate ester-containing poly(aryl ether nitrile)s Synthesis of PAEN-40 A

In a two-necked reactor, equipped with a nitrogen inlet and a mechanical stirrer, $0.436 \mathrm{~g}$ (1.91 mmol) of bisphenol A, $0.5 \mathrm{~g}(1.27 \mathrm{mmol})$ of phosphonate ester-containing bisphenol (A), $0.443 \mathrm{~g}(3.19 \mathrm{mmol})$ of 2,6-difluorobenzonitrile, $0.968 \mathrm{~g}(7.01 \mathrm{mmol})$ of potassium carbonate and $4.14 \mathrm{~mL}$ of DMSO were added and heated at $100{ }^{\circ} \mathrm{C}$ for two days. At the end of the polymerization, the reaction mixture was poured into water. The white fibrous polymers were collected by filtration, thoroughly rinsed with water and finally dried under vacuum.

Typical procedure for the synthesis of phosphonate ester-containing poly(aryl ether sulfone) Synthesis of PAES-40A

In a two-necked reactor, equipped with a nitrogen inlet and a mechanical stirrer, $0.523 \mathrm{~g}$ (2.29 mmol) of bisphenol A, $0.6 \mathrm{~g}$ (1.52 mmol) of phosphonate ester-containing bisphenol (A), $0.972 \mathrm{~g}(3.8 \mathrm{mmol})$ of 4,4'-difluorodiphenylsulfone, $1.16 \mathrm{~g}(8.4 \mathrm{mmol})$ of potassium carbonate and $6.5 \mathrm{~mL}$ of DMSO were added and heated at $80{ }^{\circ} \mathrm{C}$ for two days. At the end of the polymerization, the reaction mixture was poured into water. The white fibrous polymers were collected by filtration, thoroughly rinced with water and finally dried under vacuum.

Typical procedure for the synthesis of phosphonate ester and decafluorobiphenyl-containing poly(aryl ether)s

Synthesis of PAE $10 F-40 A$

Into a three-neck round bottom flask equipped with a mechanical stirrer and a nitrogen inlet, were charged $1.064 \mathrm{~g}$ (3.18 mmol) of decafluorobiphenyl, $0.436 \mathrm{~g}(1.91 \mathrm{mmol})$ of bisphenol A, $0.5 \mathrm{~g}(1.27 \mathrm{mmol})$ of $(\mathrm{A})$ and $0.968 \mathrm{~g}(7.01 \mathrm{mmol})$ of potassium carbonate. Then, $6 \mathrm{~mL}$ of DMAC were added and the mixture was stirred at $70{ }^{\circ} \mathrm{C}$ for $24 \mathrm{~h}$. The viscous reaction mixture was diluted with $8 \mathrm{~mL}$ of DMAC, cooled to room temperature and precipitated in water, filtered off, washed with water and methanol. The white fibrous polymer was filtered and dried at $80{ }^{\circ} \mathrm{C}$ under vacuum.

Synthesis of PAE $10 F-40 B$

Into a three-neck round bottom flask equipped with a mechanical stirrer and a nitrogen inlet, 
were charged $1.458 \mathrm{~g}(4.37 \mathrm{mmol})$ of decafluorobiphenyl, $0.5918 \mathrm{~g}(2,6 \mathrm{mmol})$ of bisphenol A, $1 \mathrm{~g}(1.73 \mathrm{mmol})$ of (B) and $1.31 \mathrm{~g}(9.5 \mathrm{mmol})$ of potassium carbonate. Then, $9 \mathrm{~mL}$ of DMAC were added and the mixture was stirred at $70{ }^{\circ} \mathrm{C}$ for $48 \mathrm{~h}$. The viscous reaction mixture was diluted with $6 \mathrm{~mL}$ of DMAC, cooled to room temperature and precipitated in water, filtered off, washed with water and methanol. The white fibrous polymer was filtered and dried at $80{ }^{\circ} \mathrm{C}$ under vacuum.

\subsection{Film elaboration}

Polymer thin films were prepared by casting $20 \mathrm{wt} \%$ polymer solutions in NMP onto a glass substrate. The films were dried under nitrogen at $50{ }^{\circ} \mathrm{C}$ overnight and successively treated one hour at $80^{\circ} \mathrm{C}, 120^{\circ} \mathrm{C}, 150^{\circ} \mathrm{C}$ and $180^{\circ} \mathrm{C}$. Films were peeled off by immersion in water. 


\section{Results and Discussion}

\section{1. Synthesis of Ethyl 4,4-di(p-hydroxyphenyl)pentanephosphonate (A)}

Monomer (A) was synthesized in three steps, according to the synthetic route depicted in Figure 2.

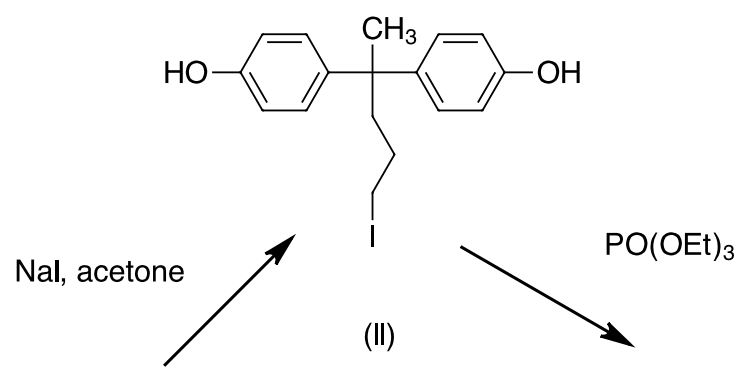

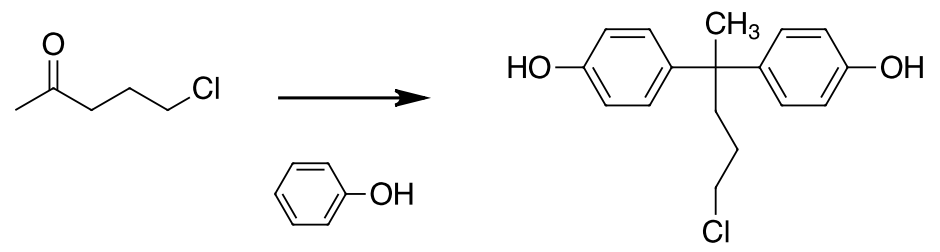

(I)

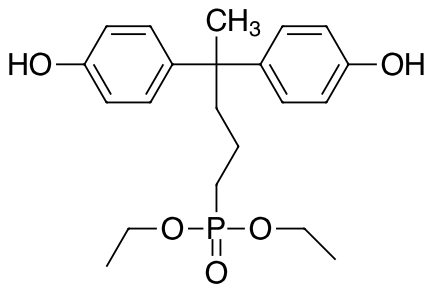

(A)

Figure 2. Synthesis of Ethyl 4,4-di(p-hydroxyphenyl)pentanephosphonate (A)

The first step is the condensation reaction of phenol with 5-chloropentanone in acidic medium leading to the formation of 1-Chloro-4,4-di(p-hydroxyphenyl)-pentane (I) (the pure product was isolated with $83.4 \%$ yield). The iodine analogue of (I) was then obtained by halogen exchange, in the presence of sodium iodide ( $74 \%$ yield). Finally, this intermediate compound (II) was reacted at $110^{\circ} \mathrm{C}$ with triethylphosphite in Arbusov reaction. The crude product was obtained with a quasi-quantitative yield. Compound (A) was obtained as a white powder. The purity of the intermediates as well as of the phosphonate-containing monomer were confirmed by HPLC (see supporting information Figure S1) and multi-nuclei NMR. ${ }^{1} \mathrm{H}$ NMR spectrum of the phosphonate ester bisphenol is reported in Figure 3. 


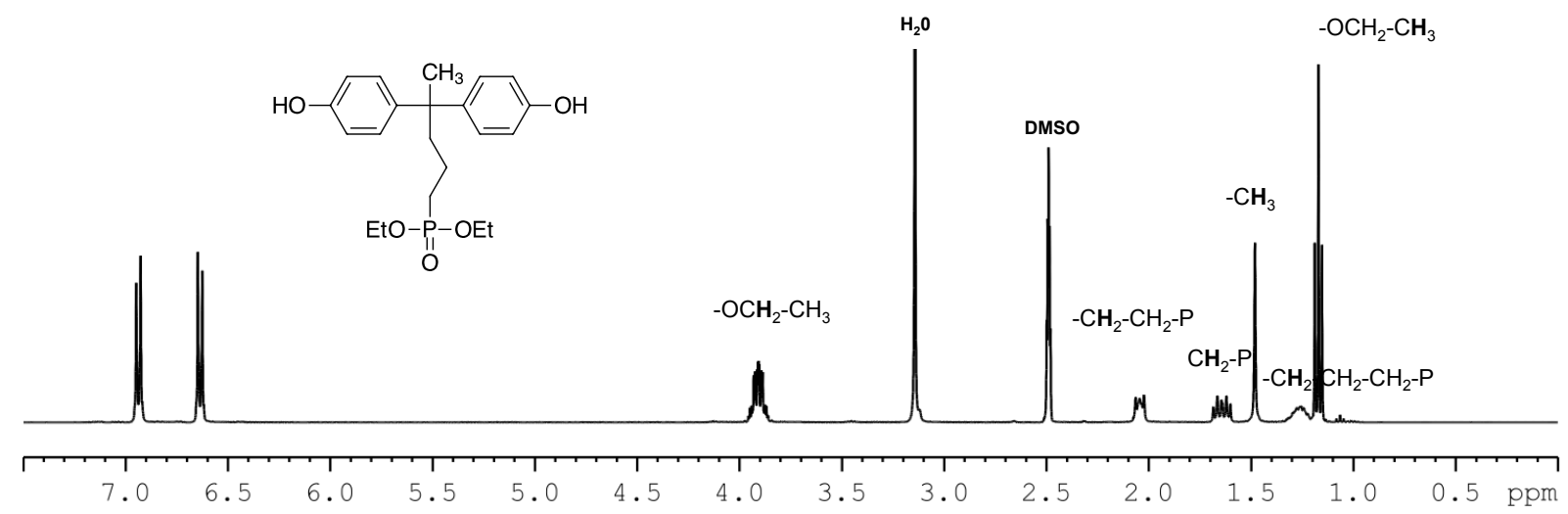

Figure $3 .{ }^{1} \mathrm{H}$ spectrum $\left(\mathrm{d}_{6}-\mathrm{DMSO}, 50^{\circ} \mathrm{C}\right)$ of compound $(\mathrm{A})$

\section{2. Synthesis of 1,1-Bis-(3,5-dimethyl-4-hydroxyphenyl)-1-(4-(3-}

diethylphosphonatopropyl)-phenyl)-2,2,2-trifluoroethane (B).
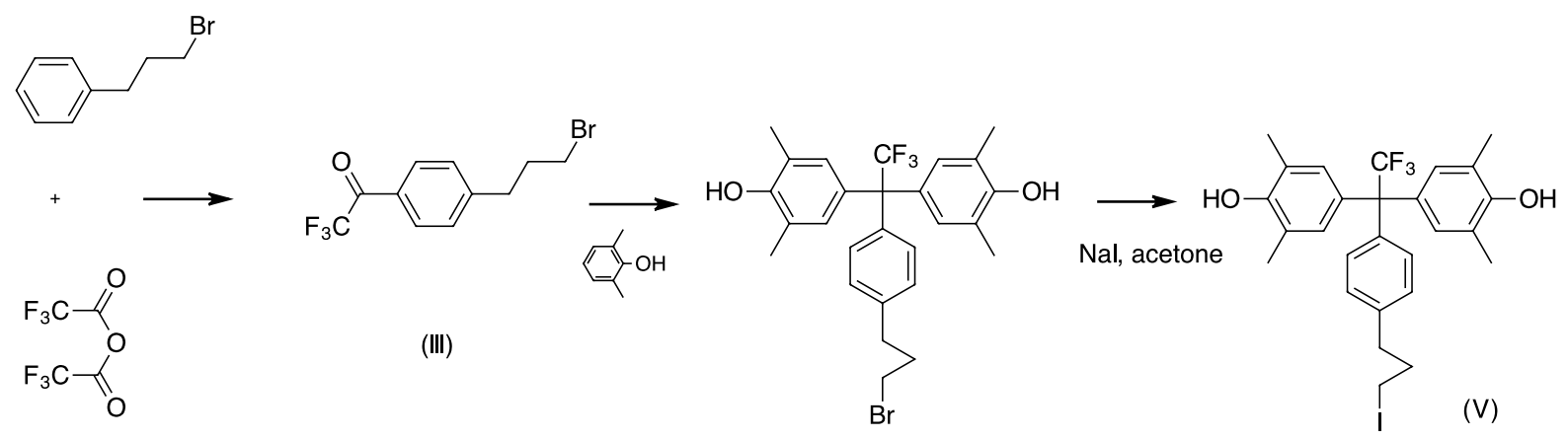

(IV)

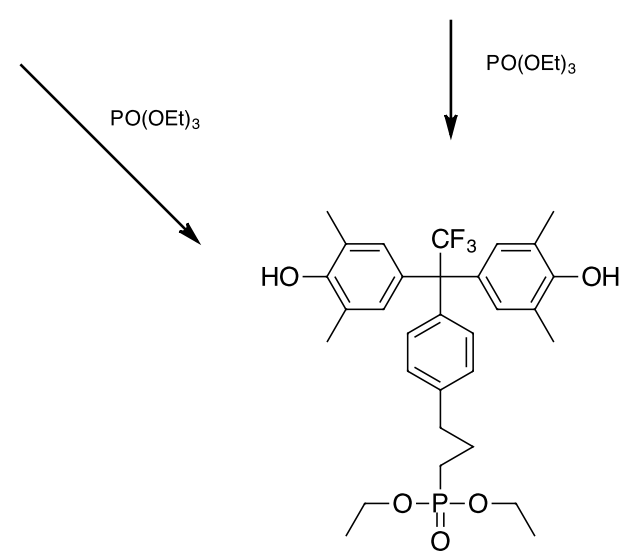

Figure 4. Multi-steps synthesis of phosphonate ester-containing bisphenol (B)

According to the synthetic pathway described in Figure 4, 1,1-Bis-(3,5-dimethyl-4hydroxyphenyl)-1-(4-(3-diethylphosphonatopropyl)-phenyl)-2,2,2-trifluoroethane (B) could be synthesized in three or four steps. First a Friedel/Crafts reaction of trifluoroacetic anhydride with 1-bromo-3 phenylpropane gives 1-bromo-3-(trifluoroacetylphenyl)-propane (III) with $86 \%$ yield. 2,6-Dimethylphenol was then condensed on this freshly distilled 
precursor in acidic medium leading to the formation of $86 \%$ of 1,1-Bis-(3,5-dimethyl-4hydroxyphenyl)-1-(4-(3-bromopropyl)-phenyl)-2,2,2-trifluoroethane (IV). This bromoalkyl compound was used without further purification in a halogen exchange reaction involving $\mathrm{NaI}$ in acetone. The Arbusov reaction could be either performed with the bromo or iodo precursors (IV and V), in the presence of triethylphosphite, at $110{ }^{\circ} \mathrm{C}$. However, a better yield was obtained with compound V. Monomer grade diethylphosphonate diphenol (B) was produced from a purification of the crude product by flash chromatography and its structure was confirmed by HPLC (see supporting informations Figure S1) and NMR characterizations. ${ }^{1} \mathrm{H}$ NMR is reported in Figure 5.

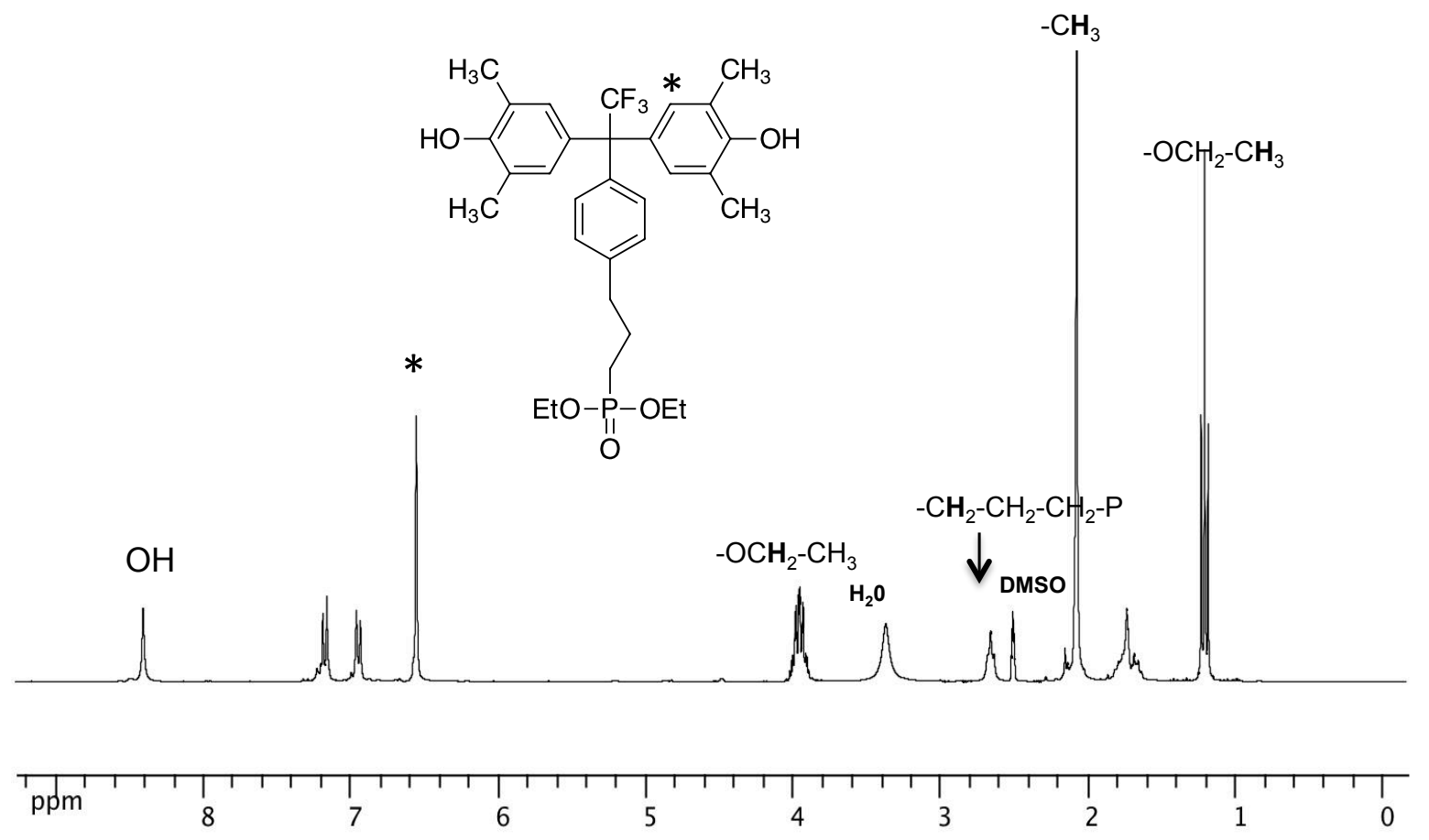

Figure 5. ${ }^{1} \mathrm{H}$ spectrum $\left(\mathrm{d}_{6}\right.$-DMSO) of compound (B)

\subsection{Regeneration of phosphonic acid groups by dealkylation}

When performed in basic conditions $(\mathrm{KOH} / \mathrm{EtOH})$, the dealkylation reaction of phosphonate esters is known to exclusively produce hemi-ester derivatives ${ }^{[51]}$. In such experimental conditions, the hemi-ester phosphonate potassium salt was characterized by a ${ }^{31} \mathrm{P}$ peak at 19.2 ppm and after re-acidification in mild conditions, the acid analogue was characterized by $\mathrm{a}^{31} \mathrm{P}$ peak at $28.5 \mathrm{ppm}$. In the frame of this work, ${ }^{31} \mathrm{P}$ NMR was used to precisely identify the structure of the phosphorus containing compounds formed. Indeed, the phosphorus atoms 
present either in a phosphonate ester, phosphonic acid or hemi-ester, both in their acid or salt forms are characterized by different resonnance peaks.

The dealkylation of the phosphonate ester-containing bisphenol (A) was performed at room temperature in acetonitrile, in the presence of chlorotrimethylsilane and sodium iodide. Such conditions are well-known to give phosphonic acid functions ${ }^{[52]}$. The evolution of the reaction was monitored by ${ }^{31} \mathrm{P}$ NMR spectroscopy. As shown in Figure 6, the peak initially present at $31.3 \mathrm{ppm}$, (characteristic of the phosphonate ester groups) progressively disappears. An intermediate compound (corresponding to the hemi-phosphonic acid analogue) is characterized by the apparition of a peak at $28.5 \mathrm{ppm}$. The final formation of the corresponding phosphonic acid bisphenol $(\mathrm{A}-\mathrm{OH})$ is confirmed by the appearance of the peak at $26.4 \mathrm{ppm}$. 


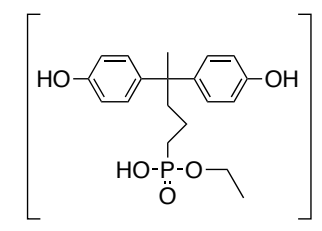

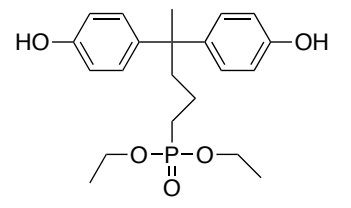

(A)

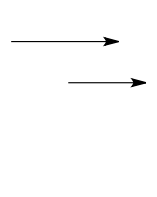

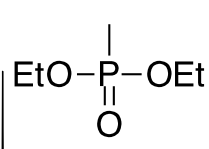

a)

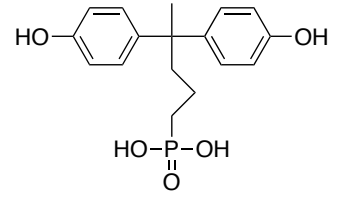

(A-OH)
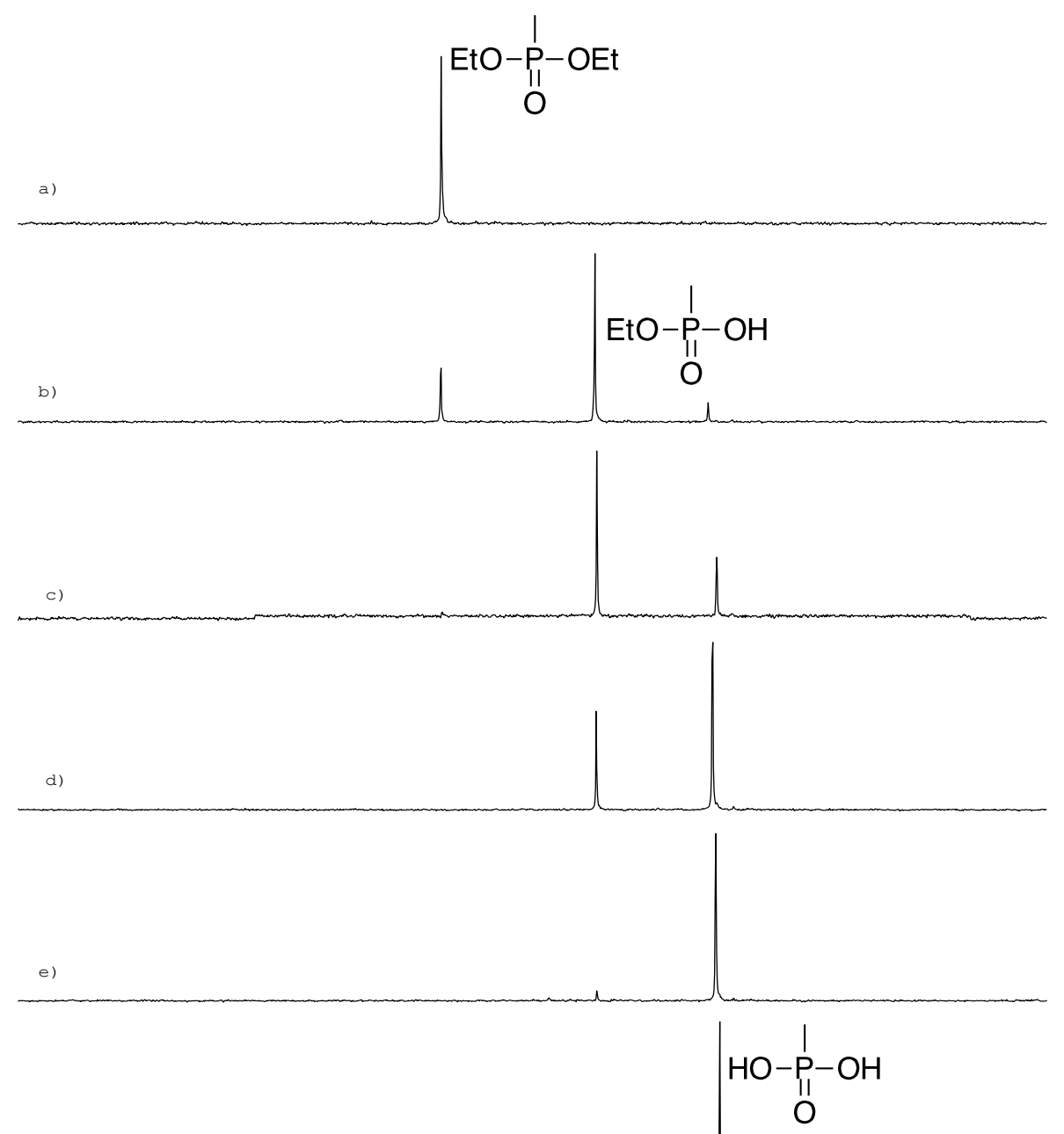

f)

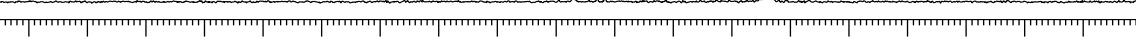

$\begin{array}{lllllllllllllllllll}39 & 38 & 37 & 36 & 35 & 34 & 33 & 32 & 31 & 30 & 29 & 28 & 27 & 26 & 25 & 24 & 23 & 22 & \mathrm{ppm}\end{array}$

Figure $6 .{ }^{31} \mathrm{P}$ NMR. (DMSO-d6, $80^{\circ} \mathrm{C}$ ). Dealkylation of bisphenol phosphonate ester (A) in its phosphonic acid analogue (A-OH). a) $t=0$ min, b) $t=10$ min, c) $t=40$ min, $d$ ) $t=3 h, e) t=2$ days,

f) 2 days + excess $\mathrm{NaI}$ 
On the ${ }^{1} \mathrm{H}$ NMR spectrum (Figure 7), the complete disparition of the triplet at $1.17 \mathrm{ppm}$ and the multiplet at 3.86-3.96 ppm, respectively associated to the protons of methyl and methylene groups of the ethyl phosphonate function confirms the formation of the phosphonic acid product.
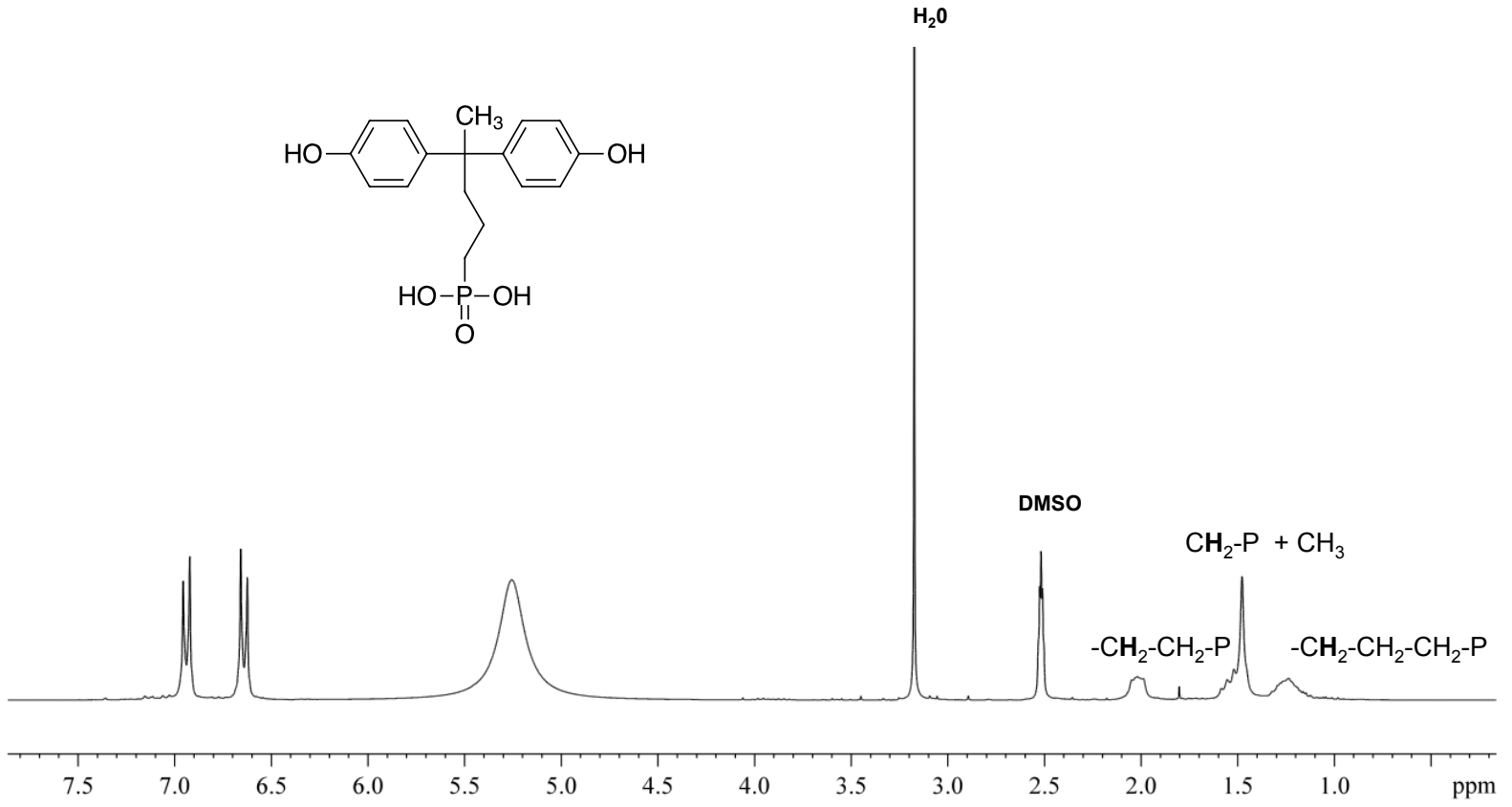

Figure 7. ${ }^{1} \mathrm{H}$ NMR spectrum of phosphonic acid containing bisphenol (A-OH).

Although the phosphonic acid bisphenol (A-OH) was isolated as a monomer-grade monomer, this precursor was rather unstable in acidic form and could not be successfully used to synthesize polymers. As a result, both phosphonate ester precursors (A and B) were directly used for polymer synthesis and phosphonic acid groups were regenerated thereafter.

\section{4. Synthesis of phosphonic acid containing poly(arylether)s (PAE)}

The phosphonate ester-containing poly(aryl ether)s were first synthesized in a polar aprotic solvent (DMSO). Bisphenol monomers (A) and (B) were polycondensed with different comonomers (4,4'-difluorobenzophenone, 2,6-difluorobenzonitrile, $4,4^{\prime}-$ difluorodiphenylsulfone or decafluorobiphenyl) as illustrated in Figure 8. 
<smiles>[Z]c1cc([Y]([X])(CCOP(=O)(OCC)OCC)c2cc([Z])c(O)c([Z])c2)cc([Z])c1O</smiles>

(A) $\quad \mathrm{X}: \mathrm{CH}_{3}, \mathrm{Y}: \mathrm{CH}_{2}, \mathrm{Z}: \mathrm{H}$

(B) $\left\{\begin{array}{l}\mathrm{X}: \mathrm{CF}_{3}, \mathrm{Y}: \square \mathrm{CH}_{2}- \\ \mathrm{Z}: \mathrm{CH}_{3}\end{array}\right.$ Polar aprotic solvent $\mathrm{K}_{2} \mathrm{CO}_{3}$

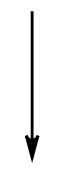<smiles>CC(C)(c1ccc(O)cc1)c1ccc(O)cc1</smiles><smiles>FC1CC2CCCC(C1)C2F</smiles>

Ar

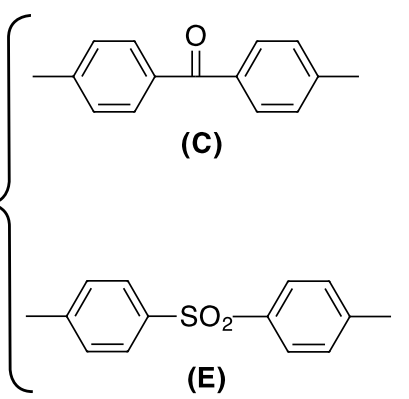

(D)

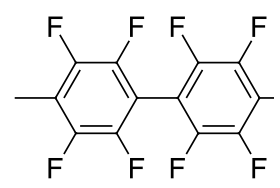

(F)

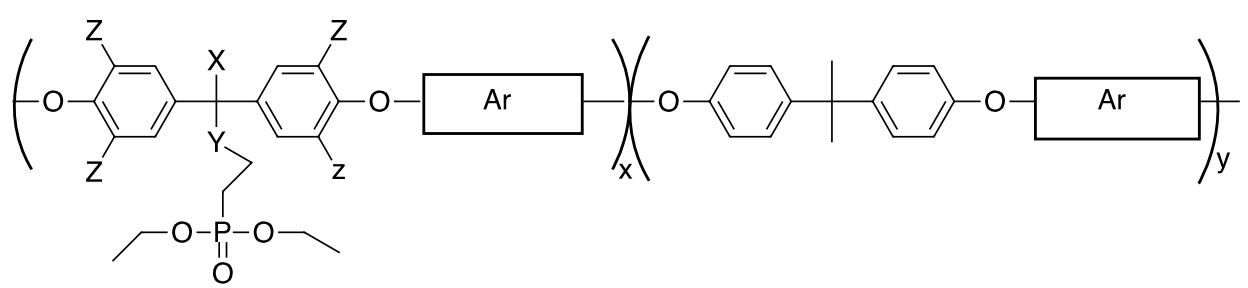

PAEK Poly(arylether)ketone PAEK (Ar=C)

PAEN Poly(arylether)nitrile ( $\mathrm{Ar}=\mathrm{D})$

PAES Poly(arylether)sulfone $(\mathrm{Ar}=\mathrm{E})$

PAE10F Poly(arylether)decafluorobiphenyl

Figure 8. Synthesis of phosphonated ester containing (PAE)s

A first series of PAEKs was prepared from monomer (A) and difluorobenzophenone as comonomer. Polymerizations were classically performed at high temperature $\left(160-180^{\circ} \mathrm{C}\right)$. The polymers were isolated in their phosphonate ester form and characterized by ${ }^{31} \mathrm{P}$ and ${ }^{1} \mathrm{H}$ NMR 


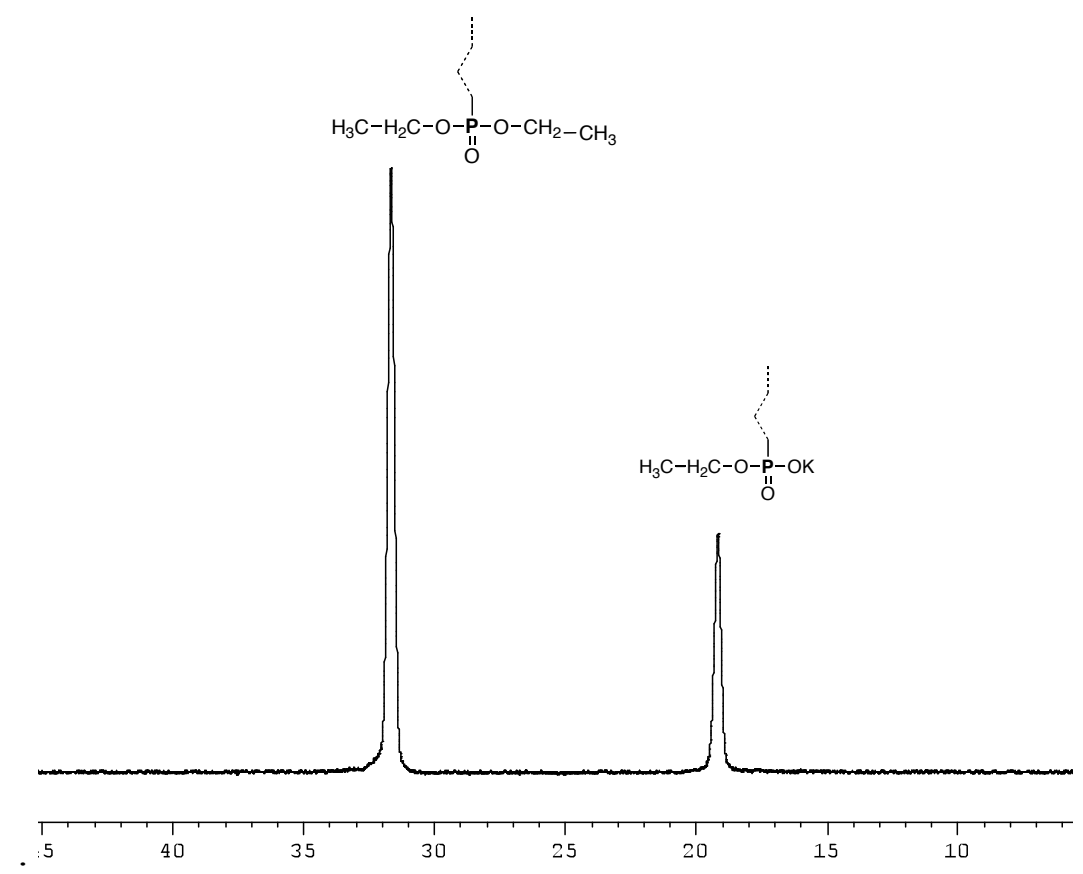

Figure 9. ${ }^{31} \mathrm{P}$ spectrum of a phosphonate ester-containing (PAE)s

${ }^{31} \mathrm{P}$ NMR spectrum (Figure 9) revealed the presence of two different phosphorus containing species. One major peak is present at $31.3 \mathrm{ppm}$ and a second one at $19.2 \mathrm{ppm}$. In the ${ }^{1} \mathrm{H}$ NMR spectrum, (see supported information (Figure S3), both the relative low proportion of the methylene and methyl groups respectively present at $3.93 \mathrm{ppm}$ and $1.18 \mathrm{ppm}$ and the presence of a second type of methylene at $3.6 \mathrm{ppm}$ and methyl at $1.03 \mathrm{ppm}$ suggest that the two phosphorus containing species respectively correspond to the expected phosphonate ester groups and to partially dealkylated groups (hemi-phosphonates, in their potassium salt form). This observation was confirmed by further ${ }^{31} \mathrm{P}$ NMR investigation (Supporting information Figure S4). Indeed, the acidification of the polymer by addition of few drops of trifluoroacetic acid (TFA) results in the protonation of the hemi-phosphonates groups, which are therefore characterized by a peak at $28.5 \mathrm{ppm}$ (figure S4 b)). In comparison, Figure S4 c) and d) correspond to the ${ }^{31} \mathrm{P}$ NMR spectra of partial and quasi-complete dealkylation of the polymer, after reflux in $\mathrm{HCl} 37 \%$. In this last case, phosphonic acid functions are characterized by a peak at $26.4 \mathrm{ppm}$.

The proportion of hemi-phosphonate groups present in the polymer at the end of the polymerization (from 22 to $61 \%$ ) was proven to strongly depend on the nature of the polymerization solvent. The results are reported in Table 1. 
Table 1. Effet of the polymerization solvent and reaction temperature on the formation of hemi-phosphonate species.

\begin{tabular}{|c|c|c|c|c|c|}
\hline Ref & $\begin{array}{c}\mathrm{PO}(\mathrm{OEt})_{2}{ }^{\mathrm{a}} \\
(\%)\end{array}$ & $\begin{array}{c}\mathrm{PO}(\mathrm{OEt})(\mathrm{OK})^{\mathrm{a}} \\
(\%)\end{array}$ & $\begin{array}{c}\mathrm{T} \\
\left({ }^{\circ} \mathrm{C}\right)\end{array}$ & Solvent & $\begin{array}{c}\text { Reaction time } \\
\text { (h) }\end{array}$ \\
\hline PAEK1 & 78 & 22 & 160 & DMSO & 24 \\
\hline PAEK2 & 61 & 39 & 180 & DMSO & 24 \\
\hline PAEK3 & 39 & 61 & 160 & NMP & 24 \\
\hline PAEK4 & 63 & 37 & 160 & DMAC & 24 \\
\hline PAEK5 & 68 & 32 & 160 & DMAC & 39 \\
\hline
\end{tabular}

After 24 hours reaction at $160^{\circ} \mathrm{C}$, only $22 \%$ of hemi-phosphonate groups were formed in DMSO whereas $37 \%$ and $61 \%$ were respectively formed in DMAC and NMP. The reaction temperature seemed to favor as well the formation of these species as in DMSO, $39 \%$ of hemiphosphonates were formed at $180^{\circ} \mathrm{C}$ (versus $22 \%$ at $160^{\circ} \mathrm{C}$ ).

The presence of $\mathrm{K}_{2} \mathrm{CO}_{3}$ during the polycondensation reaction was first suspected to induce the formation of hemi-phosphonate groups as the hydrolysis of phosphonate esters in a basic medium is well known to lead to such species. However, when diethyl[(4methylphenyl)methyl]phosphonate (Supporting information Figure S5) was heated in DMSO at $160{ }^{\circ} \mathrm{C}$ for $24 \mathrm{~h}$ in the presence of $\mathrm{K}_{2} \mathrm{CO}_{3}$, only $14 \%$ of dealkylation were determined by quantitative ${ }^{31} \mathrm{P}$ NMR. In addition, when the experience was performed at $110{ }^{\circ} \mathrm{C}$, only $3.9 \%$ of dealkylation was effective.

In both cases, the proportions of hemi-phosphonate groups formed were far lower than those observed after a polymerization reaction performed in the same conditions. Furthermore, when diethyl[(4-methylphenyl)methyl]phosphonate was heated at $160{ }^{\circ} \mathrm{C}$ in the presence of $\mathrm{K}_{2} \mathrm{CO}_{3}$ and some additional 4-fluorophenol, the proportion of hemi-phosphonate formed drastically increased. These observations suggested a possible participation of the phenate groups in this dealkylation reaction.

A dealkylation process involving exclusively the potassium carbonate should not be detrimental to the formation of high molecular weight macromolecules. Indeed, this reaction does not modify the stoechiometry ratio of monomers, which is a key parameter to obtain a polymer by polycondensation via an aromatic nucleophilic substitution reaction. However, if the phenate reagent is involved in this reaction, the polymer chain growth should be affected. To clarify this point, an investigation of a model compound obtained by reaction of the 
monomer (A) with two equivalents of 4-fluorobenzophenone, using experimental conditions similar to the polymerization conditions was performed. The resulting crude product after acidification was analyzed by NMR $\left({ }^{31} \mathrm{P},{ }^{1} \mathrm{H},{ }^{13} \mathrm{C}\right)$ and HPLC. As expected, the formation of a slightly hydrolyzed phosphonate product (16\% of hemi-phosphonate compound) was confirmed by ${ }^{31} \mathrm{P}$ NMR, by the presence of a resonnance peak at $28.5 \mathrm{ppm}$, characteristic of an hemi-phosphonate group. Moreover, besides the desired model compound which was the major product, the ${ }^{1} \mathrm{H}$ NMR clearly shows the presence of side-product(s), especially in the aromatic region (Figure 10).
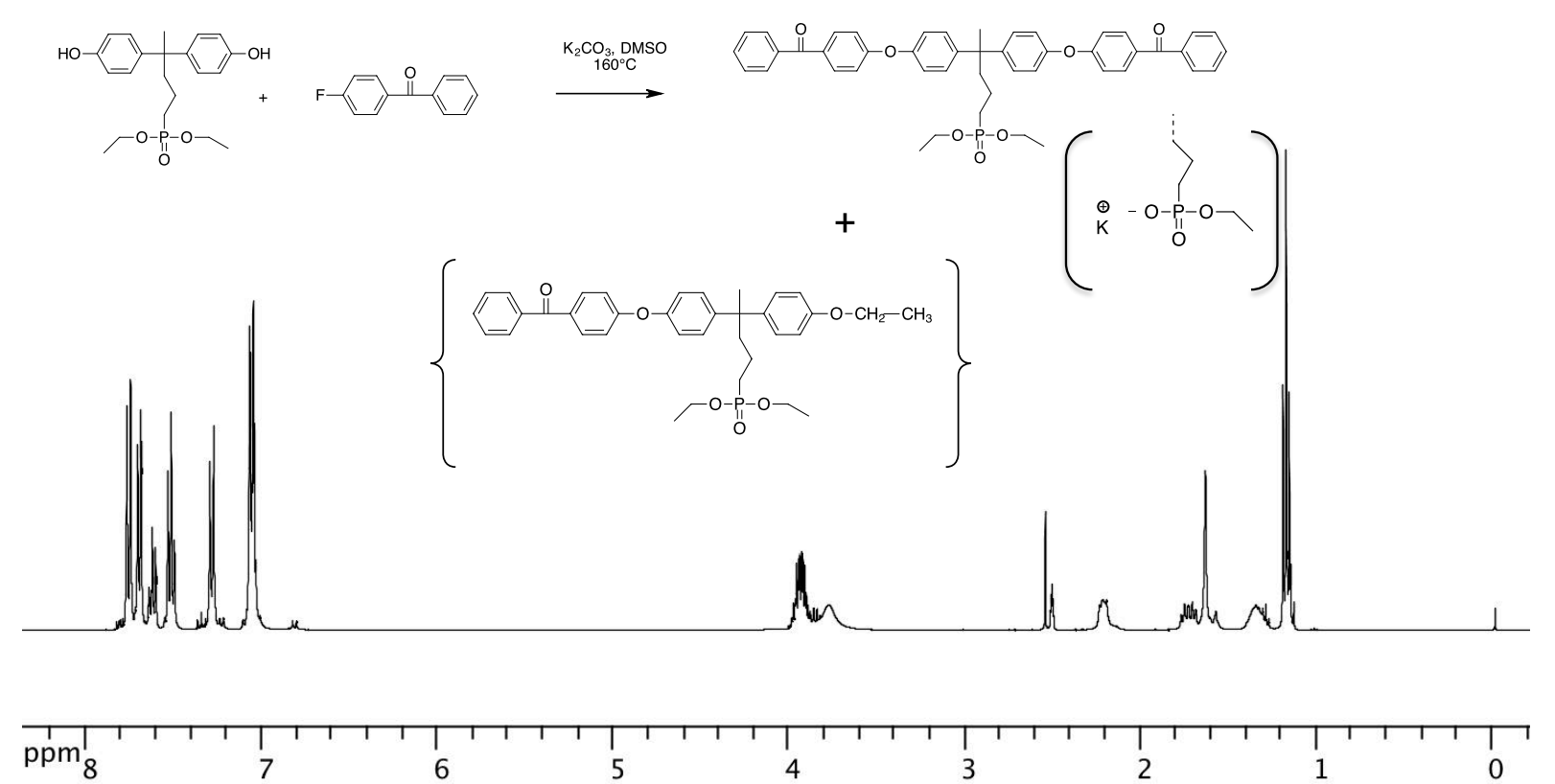

Figure 10. ${ }^{1} \mathrm{H}$ NMR spectrum of the crude model compound

Interestingly, the HPLC analysis of the crude product confirmed the presence of at least 4 different compounds (see supporting informations Figure S2). Whereas the molar mass of the two major products were determined by mass spectroscopy, the quantity of the two last minor side-products were insufficient to allow an accurate measurement. As expected, the molar mass of the main product corresponds to the desired model compound. More surprising was the identification of a second compound with a molar mass of $600 \mathrm{~g} / \mathrm{mol} .{ }^{13} \mathrm{C} \mathrm{NMR}$ analyses support the formation of the the main side -product (S), by a transetherification reaction.

${ }^{13} \mathrm{C}$ NMR analysis shows the presence of 3 different ${ }^{13} \mathrm{C}$ of methylene groups in the 55-64 ppm region (Figure 11a). The major peak, at $61.24 \mathrm{ppm}$, appears as a doublet $(6.33 \mathrm{~Hz})$ 
because of the coupling with the neighbouring phosphorus atom and corresponds to the phosphonate group of the model compound. A second peak at $60.02 \mathrm{ppm}$ also appears as a doublet $(5.83 \mathrm{~Hz})$ and was attributed to the hemi-phosphonate group formed by the partial dealkylation previouly evidenced. Finally, a third peak appearing as a singlet at $63.37 \mathrm{ppm}$ which was assigned to ${ }^{13} \mathrm{C}$ of methylene groups of a phenyl ethyl ether structure. This was confirmed in the 0-18 ppm region (Figure 11b), by the presence of three different $-\mathrm{CH}_{3}$. At $16.65 \mathrm{ppm}$, the main doublet corresponding to the phosphonate ester compound, at $16.89 \mathrm{ppm}$ a small doublet is attributed to the hemi-ester form, and the last peak at $15.12 \mathrm{ppm}$ is a singlet and characterizes the phenyl ether end group. 

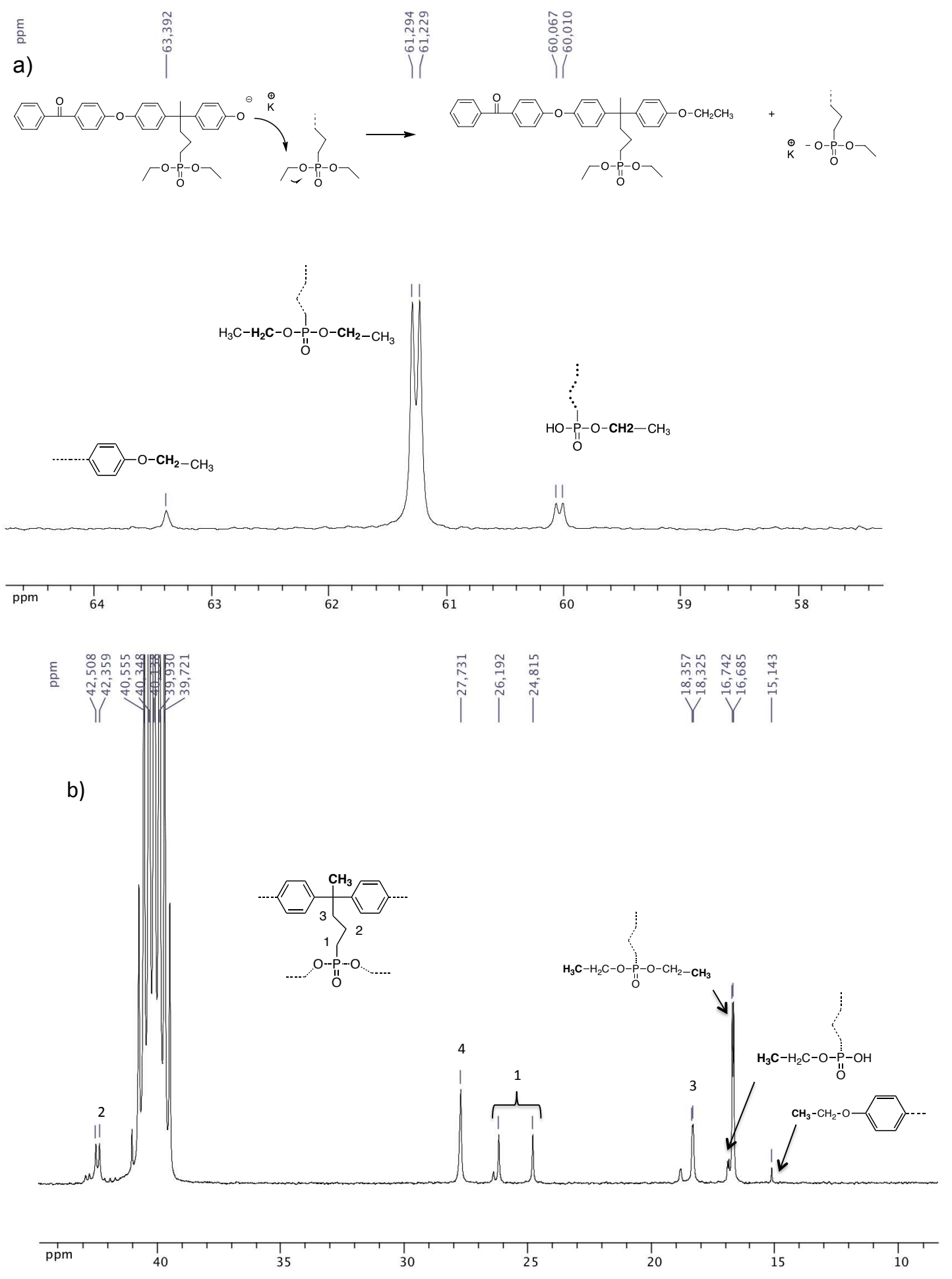

Figure 11. ${ }^{13} \mathrm{C}$ NMR (DMSO-d $\mathrm{d}_{6}, 50^{\circ} \mathrm{C}$ ) spectra (a): 58-64 ppm region, (b): 10-45 ppm region of model compound

This interpretation of results was corroborated by those obtained by a two-dimensional HSQC analysis (see supporting informations Figure S6), namely the formation of an unwanted phenyl ethyl ether side-product. One possible explanation for the formation of this 
species relies in a trans-etherification reaction between the phenate reagent and a phosphonate ester group.

Of course, such a reaction during the polymerization process should have a detrimental effect on the polymer chain growth. To avoid this problem, the reaction was performed at lower temperature and it was found that a polycondensation at temperature lower than $100^{\circ} \mathrm{C}$ was possible. The polymers based on 4,4'-difluorobenzophenone were unfortunately insoluble at this temperature and readily precipitated in the reaction medium. However, 2,6'difluorobenzonitrile was successfully polymerized and lead to the formation of high molecular weight phosphonated poly(arylether)s. A series of copolymers based on monomer (A) and bisphenol A was obtained. Polymer structures were characterized by ${ }^{1} \mathrm{H},{ }^{31} \mathrm{P}$ and ${ }^{13} \mathrm{C}$ NMR (Figure 12 and Figure 13).
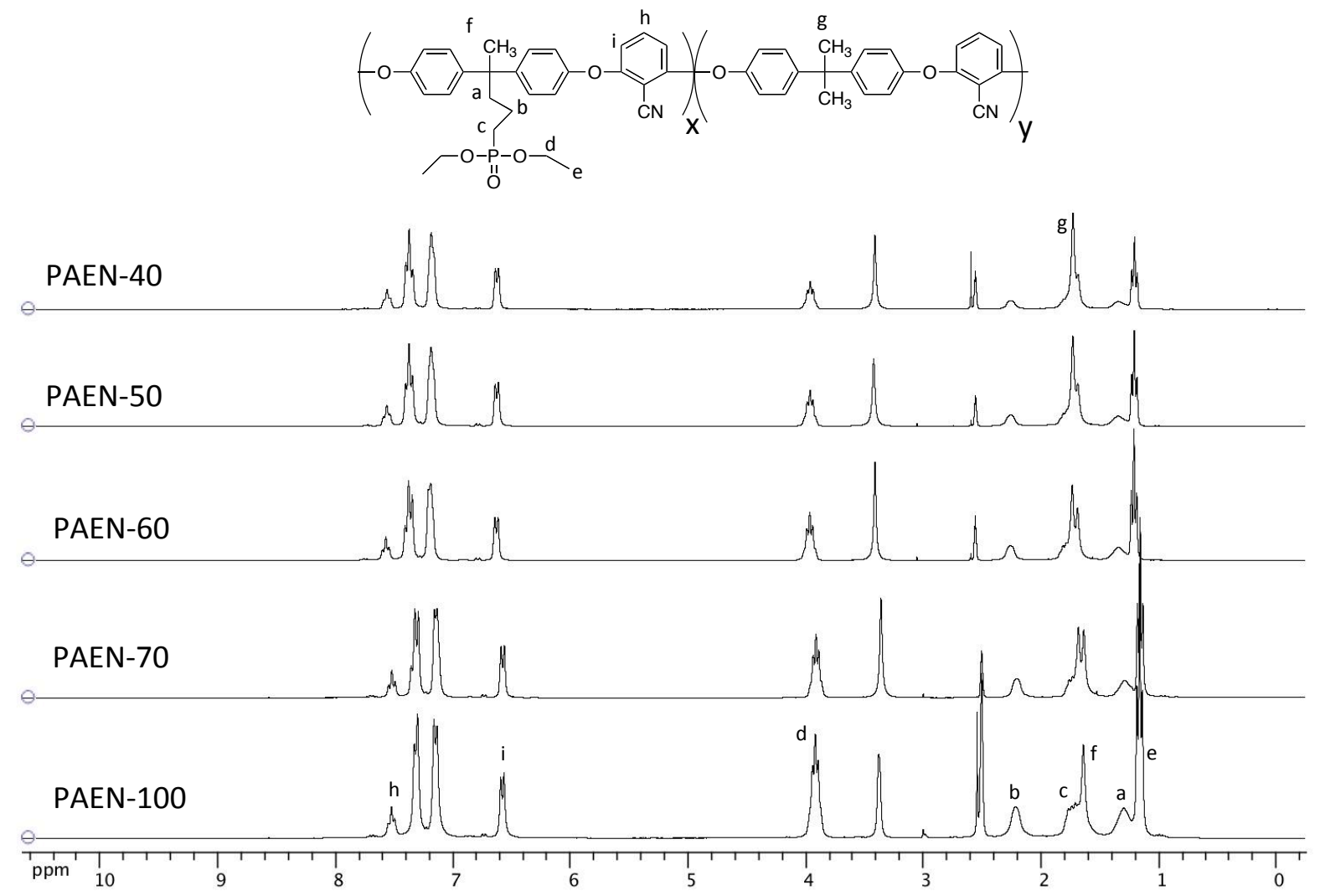

Figure 12. ${ }^{1} \mathrm{H}$ NMR (DMSO-d $\mathrm{d}_{6}$ ) spectra of phosphonate ester-containing Poly(Aryl Ether)s 


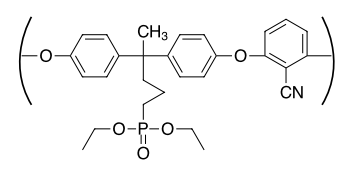

a)

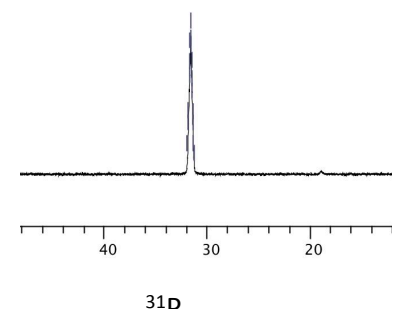

b)

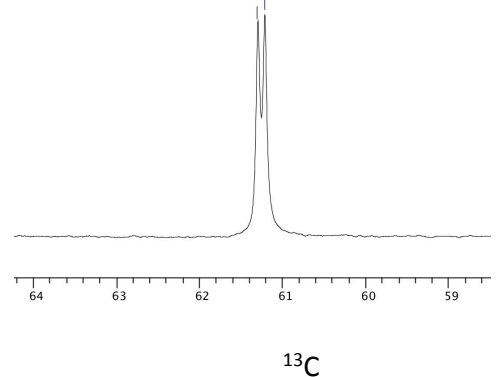

Figure 13. a) ${ }^{31} \mathrm{P}$ and $\left.\mathrm{b}\right){ }^{13} \mathrm{C}$ NMR (DMSO-d 6 ) of PAEN-100

As evidenced in Figure 13 a) less than 1.4\% of hemiphosphonate groups were determined by ${ }^{31} \mathrm{P}$ NMR, suggesting that the undesired trans-etherification side reactions were minimized. This was confirmed by the presence of a unique doublet in the 58-65 ppm region of ${ }^{13} \mathrm{C} N M R$, as reported in Figure $13 \mathrm{~b}$ ) (there is no singlet at $63.4 \mathrm{ppm}$ corresponding to $\mathrm{PHI}-\mathrm{O}-\mathrm{CH} 2 \mathrm{CH} 3$ and no doublet at $60.2 \mathrm{ppm}$ attributable to the methylene group of the hemiphosphonate is visible). In this case, the very small amount of hemi-phosphonate group formed may be ascribed to a partial dealkylation due to $\mathrm{K}_{2} \mathrm{CO}_{3}$.

Thin tough films were elaborated by the solvent casting method, from $20 \%$ wt polymer solutions in NMP. This result suggests that the polymers had high molecular weights. This was confirmed by size exclusion chromatography measurements (Table 2).

Table 2 Physico-chemical characterizations of phophonate ester-containing poly(arylether)nitriles

\begin{tabular}{|c|c|c|c|c|c|c|c|c|c|}
\hline Ref & $\begin{array}{c}\mathrm{A} \\
(\%)\end{array}$ & $\begin{array}{c}\text { BisA } \\
(\%)\end{array}$ & $\begin{array}{c}\mathrm{Mn}^{\mathrm{a}} \\
\left(\mathrm{kg} \cdot \mathrm{mol}^{-1}{ }^{1)}\right.\end{array}$ & $\begin{array}{c}\mathrm{Mw}^{\mathrm{a}} \\
\left(\mathrm{kg} \cdot \mathrm{mol}^{-1}\right)\end{array}$ & $\begin{array}{l}\mathrm{Td}_{5 \%} \\
\left({ }^{\circ} \mathrm{C}\right)\end{array}$ & $\begin{array}{c}\Delta_{\mathrm{mTh}} \\
(\%)\end{array}$ & $\begin{array}{l}\Delta_{\mathrm{m}}^{\mathrm{b}} \\
(\%)\end{array}$ & $\begin{array}{l}\mathrm{Tg}^{\mathrm{c}} \\
\left({ }^{\circ} \mathrm{C}\right)\end{array}$ & $\begin{array}{l}\mathrm{Tg}^{\mathrm{d}} \\
\left({ }^{\circ} \mathrm{C}\right)\end{array}$ \\
\hline PAEN-0 & 0 & 100 & 33.5 & 59.5 & 455 & 0 & 0 & 164 & 157 \\
\hline PAEN-40 & 40 & 60 & 50.9 & 125.9 & 330 & 6 & 7.8 & 128 & 135 \\
\hline PAEN-50 & 50 & 50 & 34.9 & 75.6 & 318 & 7.2 & 8.9 & 119 & 124 \\
\hline PAEN-60 & 60 & 40 & 35.6 & 82.6 & 322 & 8.5 & 9.7 & 108 & 116 \\
\hline PAEN-70 & 70 & 30 & 35.7 & 78.5 & 312 & 9.7 & 11.8 & 103 & 110 \\
\hline PAEN-100 & 100 & 0 & - & - & 312 & 12.2 & 13.2 & 77 & 99 \\
\hline
\end{tabular}


The thermo-oxidative stability of the polymers was evaluated by thermogravimetry analyses (Figure 14). All polymers present good thermal stability as their 5\% weight loss temperatures are above $320^{\circ} \mathrm{C}$. The first weight loss (determined at $350{ }^{\circ} \mathrm{C}$ ) corresponds to the decomposition of phosphonate ester groups in phosphonic acid analogues and ethylene, as already reported $^{[53] .}$ Condensation of two phosphonic acid groups into anhydride bridge might also occur in this temperature range. Such structures have been described and characterized

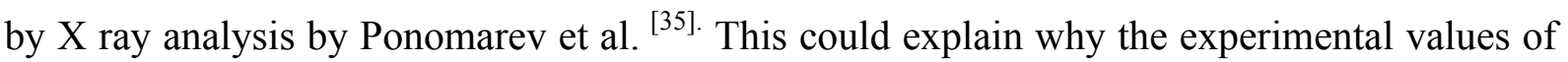
the first weight losses are slightly higher than the theoretical ones.

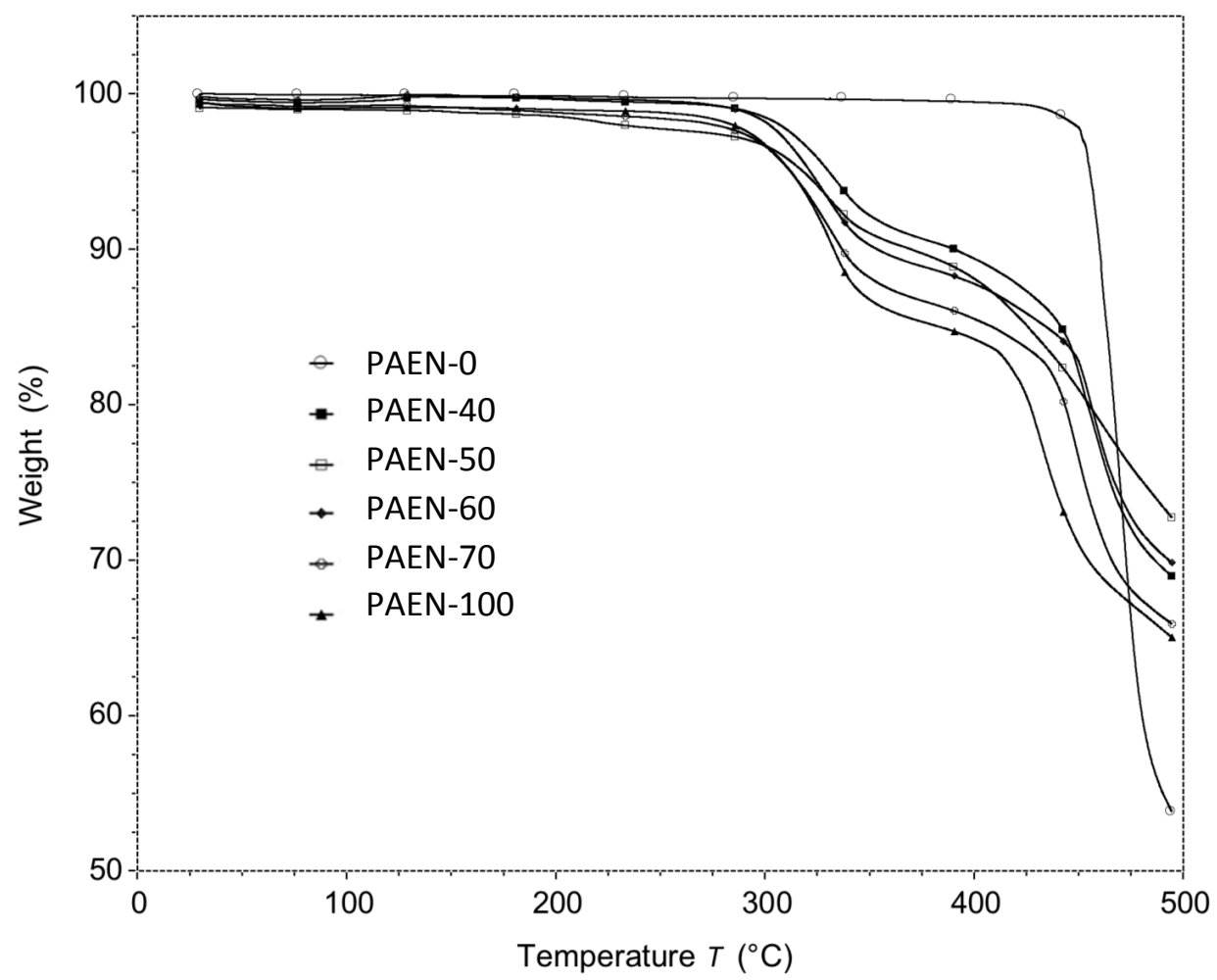

Figure 14. TGA analyses of phosphonate ester containing poly(arylether)nitriles

The glass transition temperatures were determined by DSC and TMA. Both methods evidence a drastic decrease of $\mathrm{Tg}$ as a function of phosphonate ester groups incorporated along the polymer chains. By plotting the evolution of the glass transition temperature versus the mol\% of incorporated monomer A (see supporting information Figure S7), a linear relashionship is clearly evidenced : the higher the phosphonated ester content, the lower the $\mathrm{Tg}$. This could be attributed to a plasticizing effect of the alkyl side-chain. 
Confirming that the low polymerization temperature is the key parameter to obtain high molecular weight polymers, 4,4'-difluorodiphenylsulfone (E) or decafluorobiphenyl (F) were successfully involved in polycondensation with both phosphonate esters-containing monomers (A) and (B). ${ }^{1} \mathrm{H}$ NMR characterization of such structures containing $40 \%$ of phosphonated monomer are represented in Figure 15. As evidenced on these spectra, no polymer end groups are visible, which suggest that high molecular weight polymers were synthesized. This hypothesis was confirmed by the successful preparation of tough thin membranes by solvent casting method.

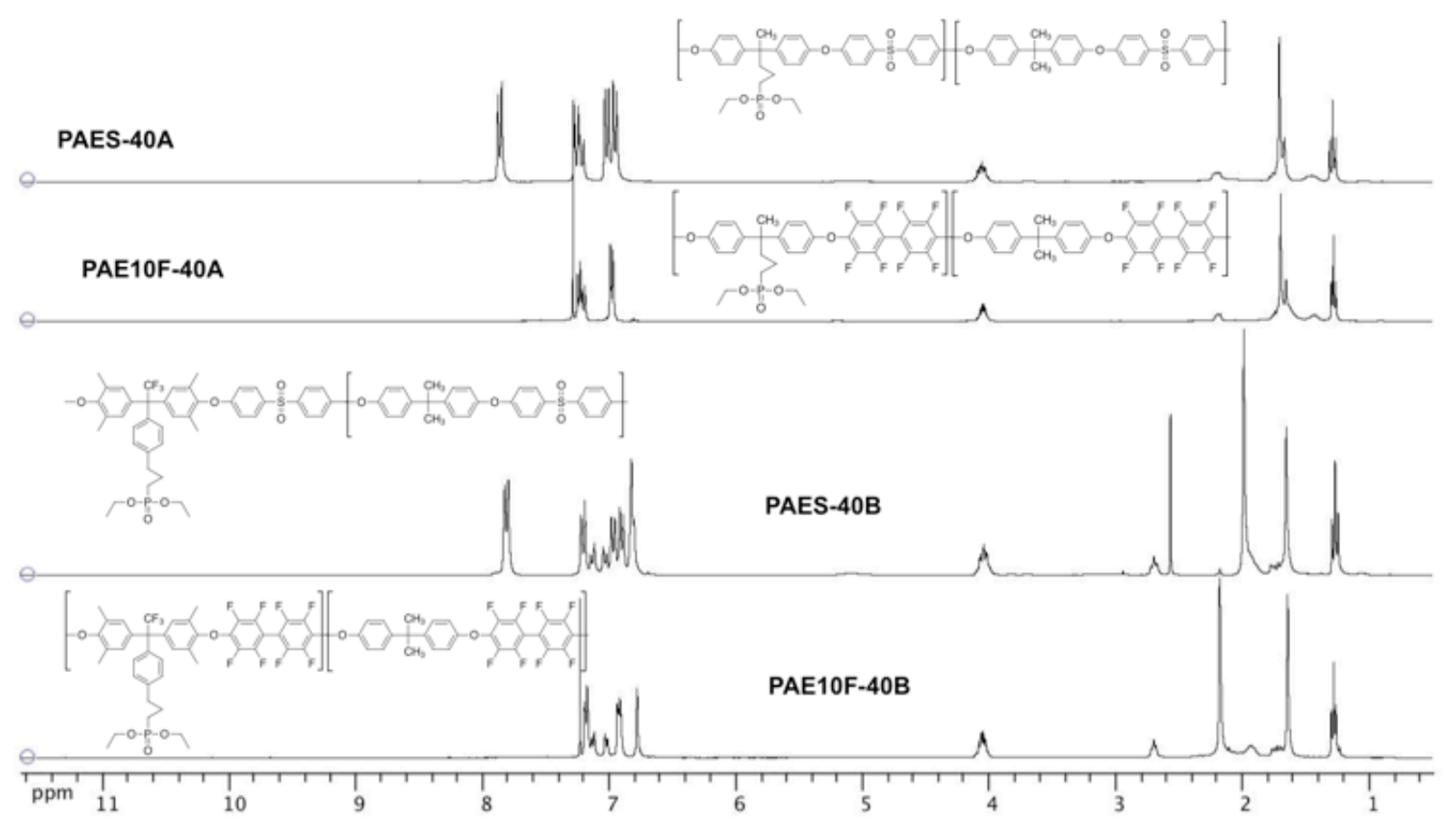

Figure 15. ${ }^{1} \mathrm{H}$ NMR $\left(\mathrm{CDCl}_{3}\right)$ characterization of a) PAES-40A, b) PAE10F-40A, c) PAES40B, PAE10F-40B

As mentioned elsewhere ${ }^{[17]}$, heating phosphonate esters at reflux in concentrated hydrochloric acid results in a complete hydrolysis of those groups into phosphonic acids. Subsequent dealkylation reaction in acidic media of the pre-cited polymers successfully led to phosphonic acid containing polymer analogues. Thorough physico-chemical characterization of such polymers will be reported elsewhere.

\section{Conclusion}

In this work, two side-chain containing phosphonate ester bisphenols were sucessfully synthesized and characterized. Whereas the dealkylated form of the precursors were not stable enough to be polymerized by aromatic nucleophilic substitution, the phosphonate ester 
analogue were incorporated in poly(aryl ether)s by direct polycondensation. When polymerizations were performed at high temperatures, the moderate molecular weights obtained were unambigoulsly attributed to undesirable trans-etherification reactions. As the reaction temperature was found to be a crucial parameter governing this side-reaction, new insights for the synthesis of hight molecular weight phosphonate esters were proposed. While performing the polymerization at mild temperature and involving highly reactive comonomers (2,6-difluorobenzonitrile, 4,4'-difluorodiphenylsulfone, decafluorobiphenyl), high molecular weight polymers containing high proportions of phosphonate ester groups were successfully synthesized. After dealkylation reaction, high molecular weight phosphonic acid containing polysulfones were obtained.

\section{Acknowlegments}

The authors thank Edouard Chauveau, Vincent Martin and Hugues Waton for organic synthesis and characterization assistance. 


\section{References}

1. $\quad$ Bardecker, J.A., Ma, H., Kim, T., Huang, F., Liu, M.S., Cheng, Y.-J., Ting, G. and Jen, A.K.Y., (2008) Self-assembled electroactive phosphonic acids on ITO: maximizing hole-injection in polymer light-emitting diodes. Adv. Funct. Mater. , 18(24), 3964-3971.

2. Catel, Y., Le Pluart, L., Madec, P.-J. and Pham, T.-N., (2010) Synthesis and photopolymerization of phosphonic acid monomers for applications in compomer materials. J. Appl. Polym. Sci. , 117(5), 2676-2687.

3. Yeniad, B., Albayrak, A.Z., Olcum, N.C. and Avci, D., (2008) Synthesis and photopolymerizations of new phosphonated monomers for dental applications. $J$. Polym. Sci., Part A: Polym. Chem. , 46(6), 2290-2299.

4. Gaboyard, M., Robin, J.-J., Hervaud, Y. and Boutevin, B., (2002) Free-radical graft copolymerization of phosphonated methacrylates onto low-density polyethylene. Journal of Applied Polymer Science, 86, 2011-2020.

5. Chougrani, K., Boutevin, B., David, G., Seabrook, S. and Loubat, C., (2008) Acrylate based anticorrosion films using novel bis-phosphonic methacrylates. J. Polym. Sci., Part A: Polym. Chem., 46(24), 7972-7984.

6. Ferrah, N., Abderrahim, O., Didi, M.A. and Villemin, D., (2011) Removal of copper ions from aqueous solutions by a new sorbent: polyethyleneiminemethylene phosphonic acid. Desalination, 269, 17-24.

7. Zhang, B., Zhang, L., Li, F., Hu, W. and Hannam, P.M., (2010) Testing the formation of Ca-phosphonate precipitates and evaluating the anionic polymers as $\mathrm{Ca}$ phosphonate precipitates and $\mathrm{CaCO} 3$ scale inhibitor in simulated cooling water. Corrosion Science, 52, 3883-3890.

8. Bock, T., Moehwald, H. and Muelhaupt, R., (2007) Arylphosphonic acidfunctionalized polyelectrolytes as fuel cell membrane material. Macromol. Chem. Phys. , 208(13), 1324-1340.

9. Rusanov, A.L., Kostoglodov, P.V., Abadie, M.J.M., Voytekunas, V.Y. and Likhachev, D.Y., (2008) Proton-conducting polymers and membranes carrying phosphonic acid groups. Adv. Polym. Sci. , 216(Fuel Cells II), 125-155.

10. Lafitte, B. and Jannasch, P., (2007) On the prospects for phosphonated polymers as proton-exchange fuel cell membranes. Adv. Fuel Cells 1, 119-185.

11. Allcock, H.R., Hofmann, M.A., Ambler, C.M. and Morford, R.V., (2002) Phenylphosphonic Acid Functionalized Poly[aryloxyphosphazenes]. Macromolecules 35(9), 3484-3489.

12. Allcock, H.R., Hofmann, M.A., Ambler, C.M., Lvov, S.N., Zhou, X.Y., Chalkova, E. and Weston, J., (2002) Phenyl phosphonic acid functionalized poly[aryloxyphosphazenes] as proton-conducting membranes for direct methanol fuel cells. J. Membr. Sci. , 201(1-2), 47-54.

13. Allcock, H.R., Hofmann, M.A. and Wood, R.M., (2001) Phosphonation of Aryloxyphosphazenes. Macromolecules 34(20), 6915-6921.

14. Allcock, H., R and Wood, R., M, (2006) Design and synthesis of ion-conductive polyphosphazenes for fuel cell applications: review. J. Polym. Sci. Part B Polym Phys, 44, 2358-2368.

15. Shaplov, A.S., Lozinskaya, E.I., Odinets, I.L., Lyssenko, K.A., Kurtova, S.A., Timofeeva, G.I., Iojoiu, C., Sanchez, J.-Y., Abadie, M.J.M., Voytekunas, V.Y. and Vygodskii, Y.S., (2008) Novel phosphonated poly(1,3,4-oxadiazole)s: Synthesis in ionic liquid and characterization. React. Funct. Polym., 68(1), 208-224. 
16. Rager, T., Schuster, M., Steininger, H. and Kreuer, K.-D., (2007) Poly(1,3-phenylene5-phosphonic acid), a fully aromatic polyelectrolyte with high ion exchange capacity. Adv. Mater. , 19(20), 3317-3321.

17. Ponomarev, I.I., Ponomarev, I.I., Petrovskii, P.V., Volkova, Y.A., Razorenov, D.Y., Goryunova, I.B., Starkova, Z.A., Fomenkov, A.I. and Khokhlov, A.R., (2010) Synthesis of N-phosphonoethylated Cardo Poly(benzimidazole) and testing of protonconducting membranes made of it. Doklady Chemistry, 432(Part2), 168-174.

18. Ponomarev, I.I., Razorenov, D.Y., Ponomarev, I.I., Volkova, Y.A., Skupov, K.M., Lysova, A.A. and Yaroslavtsev, A.B., (2019) New proton -conducting polydiimidazopyridine-based membrane for an HT-PEM fuel cell. Doklady Chemistry, 486(Part 2), 156-159.

19. Abu-Thabit, N.Y., Ali, S.A. and Javaid Zaidi, S.M., (2010) New highly phosphonated polysulfone membranes for PEM fuel cells. J. Membr. Sci. , 360(1-2), 26-33.

20. Lafitte, B. and Jannasch, P., (2005) Phosphonation of polysulfones via lithiation and reaction with chlorophosphonic acid esters. J. Polym. Sci., Part A: Polym. Chem., 43(2), 273-286.

21. Parvole, J. and Jannasch, P., (2008) Poly(arylene ether sulfone)s with phosphonic acid and bis(phosphonic acid) on short alkyl side chains for proton-exchange membranes. J. Mater. Chem. , 18(45), 5547-5556.

22. Lafitte, B. and Jannasch, P., (2007) Polysulfone ionomers functionalized with benzoyl(difluoromethylenephosphonic acid) side chains for proton conducting fuel cell membranes. J. Polym. Sci. PartA Polym Chem, 45, 269-283.

23. Tavs, P., (1970) Chem. Ber., 103, 2428-2436.

24. Balthazor, T.M. and C, G.R., (1980) Nikel-Catalyzed Arbusov reaction: Mechanistic observations. J. Org. Chem., 45, 5425-5426.

25. Jakoby, K., Peinemann, K.V. and Nunes, S.P., (2003) Palladium-catalyzed phosphonation of polyphenylsulfone. Macromol. Chem. Phys. , 204(1), 61-67.

26. Miyatake, K. and Hay, A.S., (2001) New poly(arylene ether)s with pendant phosphonic acid groups. J. Polym. Sci., Part A: Polym. Chem., 39(21), 3770-3779.

27. Liu, B., Robertson, G.P., Guiver, M.D., Shi, Z., Navessin, T. and Holdcroft, S., (2006) Fluorinated poly(aryl ether) containing a 4-bromophenyl pendant group and its phosphonated derivative. Macromol. Rapid Commun., 27(17), 1411-1417.

28. Sukumar, P.R., Wu, W., Markova, D., Uensal, O., Klapper, M. and Muellen, K., (2007) Functionalized poly(benzimidazole)s as membrane materials for fuel cells. Macromol. Chem. Phys. , 208(19-20), 2258-2267.

29. Parvole, J. and Jannasch, P., (2008) Polysulfones Grafted with Poly(vinylphosphonic acid) for Highly Proton Conducting Fuel Cell Membranes in the Hydrated and Nominally Dry State. Macromolecules 41(11), 3893-3903.

30. Alvares-Gallego, Y., Lozano, A., Ferreiro, J., Nunes, S. and De Abajo, J., in Polycondensation 2002. 25th Hamburger Macromoleculares Symposium, K. HR, Editor. 2002: Hamburg. p. 113.

31. Yasuda, T., Li, Y., Miyatake, K., Hirai, M., Nanasawa, M. and Watanabe, M., (2006) Synthesis and properties of polyimides bearing acid groups on long pendant aliphatic chains. J. Polym. Sci., Part A: Polym. Chem. , 44(13), 3995-4005.

32. Finocchiaro, P., Consiglio, G.A., Imbrogiano, A., Failla, S., Samperi, F., Sebastiano, B., Concetto, P. and Giuseppina, S., (2008) Synthesis and characterization of novel polyamides from new aromatic phosphonate diamine monomer. European Polymer Journal, 44(8), 2639-2651. 
33. Sakaguchi, Y., Kitamura, K., Nakao, J., Hamamoto, S., Tachimori, H. and Takase, S., (2001) Preparation and properties of sulfonated or phosphonated polybenzimidazoles and polybenzoxazoles. Polym. Mater. Sci. Eng. , 84, 899-900.

34. Bauer, S. and Stock, N., (2007) Synthesis and characterization of four new metal 5phosphonoisophthalates discovered by high-throughput experimentation. J. Solid State Chem., 180(11), 3111-3120.

35. Ponomarev, I.I., Rybkin, Y.Y., Goryunov, E.I., Petrovskii, P.V. and Lyssenko, K.A., (2004) Synthesis andproperties of 10-hydoxy-10-oxo-10H-1015-phenoxaphosphine2,8-dicarboxylic acid and related polybnezoimidazoles. Russian Chemical Bulletin, International Edition, 53(9), 2020-2024.

36. Ponomarev, I.I., Goryunov, E.I., Petrovskii, P.V., Ponomarev, I.I., Volkova, Y.A., Razorenov, D.Y. and Khokhlov, A.R., (2009) Synthesis of new monomer 3,3'diamino-4,4'-bis(p-diethoxyphosphoryl)methyl)phenylamino)diphenyl sulfone and polybenzimidazoles on its basis. Doklady Chemistry, 429(Part 2), 325-330.

37. Ponomarev, I.I., Razorenov, D.Y., Ponomarev, I.I., Volkova, Y.A., Skupov, K.M., Lysova, A.A. and Yaroslavtsev, A.B., (2019) Synthesis and properties of new 2,3,5,6tetraaminopyridine-based polyheteroarylenes. Doklady Chemistry, 485(Part 1), 83-86.

38. Zhu, Y., Chen, H. and He, C., (2011) Novel fluorinated polymers bearing phosphonated side chains: synthesis, characterization and properties. Journal of polymer research, 18, 1409-1416.

39. Pinto, M., Reynols, J. and Schanze, K., (2002) Polym Prep, 43(1), 139.

40. Opper, K.L., Markova, D., Klapper, M., Mullen, K. and Wagener, K.B., (2010) Precision Phosphonic Acid Functionalized Polyolefin Architectures. Macromolecules 43(8), 3690-3698.

41. Meng, Y.Z., Tjong, S.C., Hay, A.S. and Wang, S.J., (2001) Synthesis and proton conductivities of phosphonic acid containing poly-(arylene ether)s. J. Polym. Sci., Part A: Polym. Chem. , 39(19), 3218-3226.

42. Meng, Y.Z., Tjong, S.C., Hay, A.S. and Wang, S.J., (2003) Proton-exchange membrane electrolytes derived from phosphonic acid containing poly(arylene ether)s. Eur. Polym. J. , 39(3), 627-631.

43. Consiglio, G.A., Failla, S., Finocchiaro, P. and Siracusa, V., (1998) Synthesis of new ortho-hydroxy aryl phosphonate monomers. Phosphorus, Sulfur Silicon Relat. Elem., 134/135, 413-418.

44. Mou, L., Singh, G. and Nicholson, J.W., (2000) Synthesis of a hydrophilic phosphonic acid monomer for dental materials. Chem. Commun., (5), 345-346.

45. Consiglio, G.A., Failla, S., Finocchiaro, P. and Siracusa, V., (2002) Synthesis and Characterization of New Ortho-Acetyl or Ortho-bis-p-aminophenoxy Phosphonate Monomers. Phosphorus, Sulfur Silicon Relat. Elem. , 177(11), 2561-2569.

46. Dhawan, B. and Redmore, D., (1984) o-Hydroxyaryl diphosphonic acids. J. Org. Chem., 49(21), 4018-21.

47. Abouzari-Loft, E., Ghassemi, H., Shockravi, A., Zawodzinski, T. and Schiraldi, D., (2011) Phosphonated poly(arylene ether)s as potentaial high temperature proton conducting materials. Polymer, 52, 4709-4717.

48. Papadimitriou, K.D., Andreopoulou, A.K. and Kallitsis, J.K., (2010) Phosphonated fully aromatic polyethers for PEMFCs applications. J. Polym. Sci., Part A: Polym. Chem. , 48(13), 2817-2827.

49. Zhang, X., Yue, B., Yan, L., Zeng, G. and Tao, S., (2016) International Journal of Hydrogen Energy, 41, 4740. 
50. Meng, Y.Z., Tjong, S.C., Hay, A.S. and Wang, S.J., (2003) Proton exchange membrane electrolytes derived from phosphonic acid containing poly(arylene ether)s. European Polymer Journal, 39, 627-631.

51. Rabinowitz, R., (1960) Synthesis of monoesters of phosphonic acids. J. A. C. S., 82, 4567-4567.

52. Sellen, M., Baeckvall, J.E. and Helquist, P., (1991) Synthesis of substituted cyclic 1,3dienes via selective 1,4-elimination of benzenesulfinic acid from allylic phenyl sulfones. J. Org. Chem. , 56(2), 835-9.

53. Kotov, S.V., Pedersen, S.D., Qiu, W., Qiu, Z.-M. and Burton, D.J., (1997) Preparation of perfluorocarbon polymers containing phosphonic acid groups. J. Fluorine Chem. , 82(1), 13-19. 